\title{
Effectiveness of measures to reduce the influence of global cli- mate change on tomato cultivation in solariums. Case study: Crişurilor Plain, Bihor, Romania.
}

\author{
Mihai Cărbunar'1, Olimpia Mintaș², Nicu Cornel Sabău ${ }^{3^{*}}$, Ioana Borza ${ }^{1}$, Alina Stanciu ${ }^{1}$, Ana Pereș${ }^{3}$ Adelina Venig ${ }^{3}$, \\ Mircea Curilă ${ }^{3}$, Mihaela Lavinia Cărbunar ${ }^{1}$, Teodora Vidican ${ }^{1}$ and Cristian Oneț ${ }^{3 *}$ \\ 1 University of Oradea, Faculty of Environmental Protection, Department of Agriculture-Horticulture, 26 \\ Magheru Street, 410048, Oradea, Romania; carbunar@yahoo.com; borzaioanamaria@yahoo.com; as1stan- \\ ciu@yahoo.com; mihaelacarbunar@yahoo.com; iuliateodora68@yahoo.com; \\ 2 University of Oradea, Faculty of Environmental Protection, Department of Animal Science and Agritour- \\ ism, 1 University Street, 410087 Oradea, Romania; buzasiu@yahoo.com; \\ ${ }^{3}$ University of Oradea, Faculty of Environmental Protection, Department of Environmental Engineering, 26 \\ Magheru Street, 410048, Oradea, Romania; nsabau@uoradea.ro; peresana35@yahoo.com; mirceacurila@ya- \\ hoo.com; adelina venig@yahoo.com; cristyonet78@gmail.com \\ * Correspondence: nsabau@uoradea.ro; (NCS) cristyonet78@gmail.com (CO)
}

\begin{abstract}
Tomatoes, one of the most appreciated vegetables consumed, are crops well adapted for cultivation in arid and semi-arid conditions, the success of large yields is guaranteed by covering water consumption through irrigation. Solar Pumps - SP are driven by Photovoltaic Panels - PV (SPAPV), eliminating the dependence on electricity or diesel; they are environmentally friendly because they generate carbon-free electricity and the cost of operation and maintenance is lower. In order to preserve the water administered by drip to the tomato crop grown in solariums, mulching is used. In Husasău de Tinca, in the Crișurilor Plain, cultivation of tomato varieties without mulching (WM) and with mulching with black foil (MBF) were studied. To answer the question "How effective are water conservation measures in terms of energy independence?", two variants of SPAPVs, direct pumping (ADP) and storage tank (AST) were simulated. Considering the conditions in the solariums, tomato crops do not benefit from the contribution of precipitation, therefore it is proposed to determine the water consumption of tomatoes (ETRo), using the temperatures inside the solarium. In 2016, the average temperatures during the vegetation period were observed with an insurance of over $20 \%$, the irrigation norms were $6945.7 \mathrm{~m}^{3} \mathrm{ha}^{-1}$, for the WM variant and 6594.0 $\mathrm{m}^{3} \mathrm{ha}^{-1}$ for the MBF variant, respectively. Specific Investment (SI) is 214,795 Euro ha-1 in case of ADP and respectively 202,990 Euro ha ${ }^{-1}$ in case of ATS. The payback period (IPT) is between 2.68 years and 2.53 years for the ADP variant and between 1.63 years and 1.54 years for the ATS variant, respectively. The indications for water use and irrigation water use show that in the MBF variant the water administered by localized irrigation is better utilized than in the WM variant. In the conditions of Crișurilor Plain, the best solution for the distribution of water in solariums, with the help of SPAPVs is the mulching system of tomatoes grown in solariums (MBF) and the arrangement of the drip irrigation system with a water storage tank (ATS).
\end{abstract}

Keywords: tomatoes; drip irrigation; mulching; solar pump; photovoltaic panel; economic indices; irrigation water indices;

\section{Introduction}

Global population growth and climate change are among the biggest challenges facing the world. To these are added the health crisis, caused by COVID, 19 and the energy crisis, which is manifested by the continuous increase of energy prices $[1,2,3]$. The general effects of climate change are visible through the negative influences on the water circuit in 
nature, manifested by changing the distribution, in time and space of the atmospheric water cycle, with clear trends to increase the coefficient of variation [4]. The increase of the coefficient of variation indicates both the increase of floods frequency and droughts frequency, which are accompanied by an obvious tendency to increase the temperatures value $[5,6]$. Due to their persistence, they lead to land degradation through desertification, with negative implications on the possibilities of providing water for industry, agriculture and the supply of drinking water to the population [7, 8].

The complex effects of climate change on agriculture are manifested by reducing water reserves in the soil, drastically reducing the accessibility of water to plants, declining agricultural production and thus reducing the diversity, structure, composition and distribution of crop plants $[9,10,11]$. It is estimated that the main climatic element responsible for the growth and production of crops is temperature, which influences, together with precipitation, evapotranspiration (ET), which is, through the two components (evaporation + perspiration) the way to measure the consumption of water of crops $[12,13,14]$. The trend of evolution of water consumption of crops, in arid conditions is increasing, a trend imposed by the evaporation component of consumption [15, 16, 17]. Under these conditions, the need of water for crops is provided to a lesser extent by atmospheric precipitation, and it is necessary to complete it by irrigation $[18,19,20]$. Given that in times of drought, even natural water reserve is limited, by principles of sustainable agriculture, it is necessary to use early warning systems for droughts and apply effective management [21, 22, $23,24]$. Due to increasing water requirements for crops, efficient management of water resources in agriculture means efficient use of irrigation water, conservation of soil water supply, and reduction of energy consumption for irrigation [25, 26, 27, 28].

The energy consumption in the agri-food sector is high, with high values of consumption, plant production, animal husbandry and the transport of agricultural products and agricultural machinery, fertilizers, pesticides, etc. [29]. The structure of energy sources is very varied, in 2018, in EU countries, non-renewable energy, produced by burning fossil fuels is still $60 \%$ [30]. If we analyze the plant production sector, we notice the preponderance of energy produced by burning liquid fossil fuels, derived from crude oil, for agricultural machinery involved in mechanized agricultural work and high electricity consumption, necessary for pumping large volumes of water used for irrigation. [31]. At the same time, the agricultural sector contributes with $10-12 \%$ of its total greenhouse gas emissions annually [32]. Action must be taken to reduce the effects of global climate change and improve the quality of the environment by reducing greenhouse gas emissions in agriculture by requiring the gradual replacement of fossil fuel sources with energy from renewable sources, biomass, wind or solar [33,34,35]. Given that in agriculture, the highest consumption of electricity is used for pumping irrigation water, the use of solar energy to produce the necessary electricity has several advantages: high development potential; energy independence; low impact on the environment due to the reduction of greenhouse gas emissions; economic efficiency [36].

Considering that the water pumping for irrigation is power consuming, since the 1970s, it has been proposed to use renewable sources of pumping energy, and particularly photovoltaic energy [37]. Then came solar pumps, pumps powered directly by electricity produced by photovoltaic panels (PV) whose use has seen a spectacular development, being eloquent the interest in the performance of Water Pump Systems with Photovoltaic Panels (SPAPV) [38]. In the absence of electricity supply networks, PVs are viable solutions for agriculture, being cheaper than pumps powered by liquid fuel engines. The increase of oil prices and the reduction of PV production costs by $30-60 \%$ in the last 10 years, from 76 USD / Wat in 1977 to 0.30 USD / Wat in 2015, makes the use of SPAPVs more attractive to decision-makers, technicians and users [39].

SPAPVs used for water pumping have several remarkable advantages: they reduce or eliminate dependence on electricity or diesel; they are environmentally friendly because they generate carbon-free electricity; the cost of operation and maintenance is lower, the tendency to reduce investment [40]. Water pumping with systems powered by energy produced by PV is used more and more for domestic water supply [41], for population 
and animals in arid and semi-arid rural areas [4242]. SPAPVs are effective solutions for irrigating isolated areas, with a convenient distribution of daily sunshine and global solar radiation [43]. Solar pumps (SP) are driven by electric motors powered by PV. The electric motors used can run on direct current or alternating current. In the case of alternative current motors, it is necessary to add an inverter to the system construction, which converts the direct current produced by the solar panel into alternating current. The efficiency of PV depends, in addition to the duration of solar radiation and the ambient temperature, which has negative influences. Besides, the performances of SPAPVs are directly influenced by the climatic conditions of the area [44]. Moreover, research on optimizing the pumped water flow, aimed to establish the maximum power point of PVs, depending on the mode of coupling in series or in parallel, using modeling, with the help of artificial neural networks [45]. In the case of mixed PV coupling, the best performances are obtained for solar pumps. Numerous researches on the architecture of SPAPV have shown that, in order to improve the efficiency of water use, increase distribution uniformity and increase yield, at directly pumping systems [46], (that pump water only when PV captures solar radiation), water storage tanks [47], or accumulators (batteries) have to be added. The arrangements for localized irrigation with a water storage tank allow the administration of water to the plant when the energy generated by PV is not enough [48]. The SPAPV can be easily installed near the place of consumption, and the area occupied by PV can be optimized, which is why they are often used for irrigating tomatoes grown in solariums [49]. In addition, the use of SPAPVs for drip irrigation allows the complete automation of the warning and forecast of the application of the irrigation norms necessary to complete the soil moisture [5050].

The main condition that an irrigation system fed by a SPAPV must meet is to ensure the optimal water consumption of the crop, which is the amount of water consumed by one hectare of crop during the vegetation period and which ensures maximum yield [51]. Because the water requirement of a crop is composed of the amount of water lost from the soil reserve by evaporation and the amount of water consumed by the crop through perspiration, for consumption, the notion of evapotranspiration (ET) is used [52]. A lot of methods for determining the water consumption of crops (evapotranspiration of crops) are presented in the specialty literature, each of them being adapted to the purpose (determining the need for irrigation water), natural conditions in the analyzed area, endowment with specialized equipment and last but not least, the available climate database [53, 54]. Depending on how the ET is evaluated, the literature mentions: potential evapotranspiration (PET), the reference evapotranspiration (ETRo), the actual evapotranspiration (ETa) [55]. PET is the rate of water transfer, from a moist soil, by evaporation to the surface and the transpiration of plants, in conditions of balance between the water reserve in the soil, the water consumption of the crop and the atmospheric conditions. PET has a more general, ambiguous interpretation, being the amount of water that could be consumed from the soil reserve under ideal conditions. [56]. ETRo refers to the amount of water lost through evaporation and perspiration of a grassy surface, maintained at a low height, considered the reference crop. ETRo eliminates PET-related ambiguities and allows a more realistic characterization of the effect of microclimate on the evaporative transfer from the soil-plant system to the atmosphere, above a cultivated area [57]. ETa represents the current water consumption of crops, determined for a certain period of time, in experimental fields, by calculating the water balance in the soil [58].

If for the plants grown in the open field, part of the water consumption is covered by rainfall and the water reserve in the soil, in the case of indoor crops the rainfall is missing, which is why ET must be covered by irrigation. In the case of SPAPV used for irrigation in field crops, they have the advantage that in rainy periods, when the sky is overcast, their operation is not necessary, water pumping is necessary in periods without precipitation, with clear skies, when global solar radiation is maximum. On the contrary, in the case of irrigation of plants grown indoors, SPAPV must also pump water during periods of cloudy skies [40]. 
Tomatoes (Solanum lycopersicum L. Lycopersicon esculentum Mill), due to their low caloric value and high vitamin content, are among the most popular fresh vegetables, which is why, all over the world there is interest in increasing production. Moreover, organic tomatoes grown in solariums, in the current global climate change, present a great challenge in terms of water consumption management and economic efficiency. Under these conditions, especially in arid and semi-arid areas, water becomes a limited economic resource, the largest consumer being the agriculture, which uses it mainly for crop irrigation. Efficient use of water for irrigation, in order to achieve the highest possible yields and to save water, requires the use of efficient irrigation methods, such as localized irrigation, avoidance of water loss, warning and scheduling of irrigation management [59].

The water consumption of tomatoes is very different, depending on the type of crop (field or solarium) and the climatic conditions of the year considered. In the period 20172019 , tomatoes grown in the field consume an average of $3949.7 \mathrm{~m}^{3} \mathrm{ha}^{-1}$, of which 2170.0 $\mathrm{m}^{3} \mathrm{ha}^{-1}$ are covered by rainfall and soil water reserve [60]. The average ET (2000 - 2002) of the solar grown tomatoes, was between 4232.8 and $4821.9 \mathrm{~m}^{3} \mathrm{ha}^{-1}$ [61]. ET in greenhouse conditions, estimated by measuring sap flow under stress conditions, is between 2234.1 and $2921.8 \mathrm{~m}^{3} \mathrm{ha}^{-1}$ [62]. For the conditions in the Crișurilor Plain, from Husasău de Tinca, the average consumption of tomatoes grown in solariums (1999-2001) was $7090 \mathrm{~m}^{3} \mathrm{ha}^{1}$, of which $5180 \mathrm{~m}^{3} \mathrm{ha}^{-1}$ were covered by irrigation and the remaining $269 \mathrm{~m}^{3} \mathrm{ha}^{-1}$ of soil water reserve [6363]. These differences may also be due to the fact that the design of irrigation systems uses precipitation, with a $20 \%$ non-exceedance insurance, recorded over a period of about 30 years. The assurance of not exceeding the value Xi, from a series of observations $\mathrm{Xn}$, indicates the frequency of the years in which the observed values will be lower than the considered value Xi. If we take into account the fact that under controlled conditions, precipitation does not participate in supplementing crop consumption and that the recorded temperatures are those used to determine the ET, it is proposed to use for this, the average annual temperature with $20 \%$ insurance [56].

Given that tomatoes are well adapted for cultivation in arid and semi-arid conditions, the success of large yields, both in the case of those grown in the field and in closed areas (solariums) is guaranteed by the coverage of water consumption by irrigation. Research on field-grown tomatoes in Szarvas, Hungary, with different drip irrigation standards has shown that, under appropriate agrotechnical conditions, production increases in proportion to the irrigation rate administered, reaching up to 90-110 to ha-1 [60]. The average yield of tomatoes, for a period of three years (2000-2002) grown in solariums, drip irrigated with irrigation norms to cover the optimal consumption, in the area of the Someșan Plateau, was 78.7 to ha-1 [61]. In the conditions from Crișurilor Plain, the average yields (1999-2001) obtained for organically grown tomatoes in solariums, drip irrigated, at Husasău de Tinca, was 87.9 to ha $^{-1}$ for the non-mulched (WM) variants and 111.6 to ha-1 , respectively, for the mulched with black foil (MBF) variants [64].

Due to the current global climate change, the rising price of electricity, and the fact that the irrigation of tomatoes in Husasău de Tincă is done by drip, using a pump powered by electricity from the national grid, the aim is to achieve energy independence by using the SPAPVs. Given that water consumption of tomatoes grown in solariums is expected to increase, and that alternatives to water conservation from soil by mulching have been tested, it is interesting how effective are the means of reducing the effects of climate change on tomatoes grown in solariums? (Figure 1)

The main objective of this paper is to use the guided simulation of an operational SPAPV (with direct pumping - ADP and with a water storage tank - ATS) from Husasău de Tinca, to highlight the efficiency of some soil-water conservation methods (mulching with black foil - MBF) in the conditions of Crișurilor Plain. In order to achieve this objective, a number of economic indicators (The surface that can be cultivated, Specific investment - SI, Investment payback time - IPT) and indicators of water use (Water Use Coefficient - WUC; Irrigation Water Use Coefficient - IWUC; Water Use Efficiency - WUE; Irrigation Water Use Efficiency - IWUE) have been determined. 


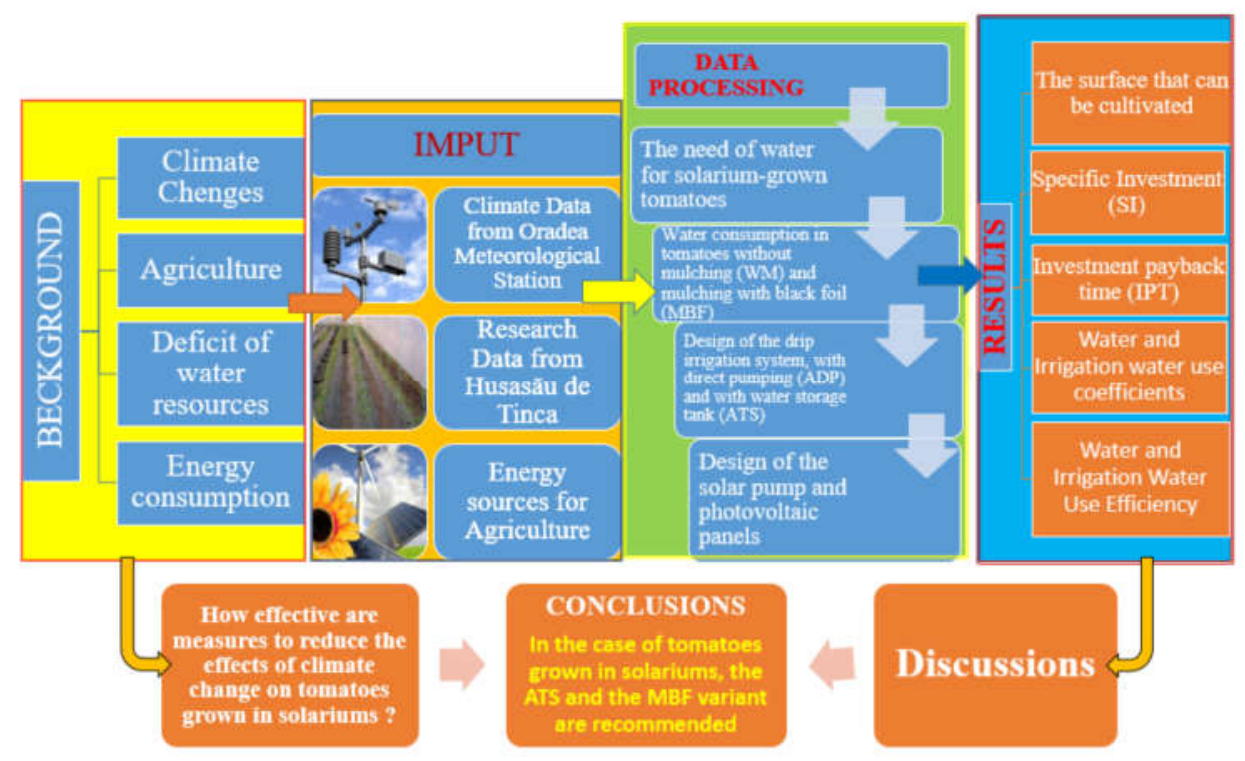

Figure 1. Graphical abstract

\section{Materials and Methods}

2.1. Location of the experimental field from Husasău de Tinca, Bihor County.

The present case study is located in the Crișurilor Plain, in Husasău de Tinca, Bihor County, where there are 4 solariums arranged for drip irrigation, in which, the influence of foil type and mulching on tomato production was studied (Figure 2).

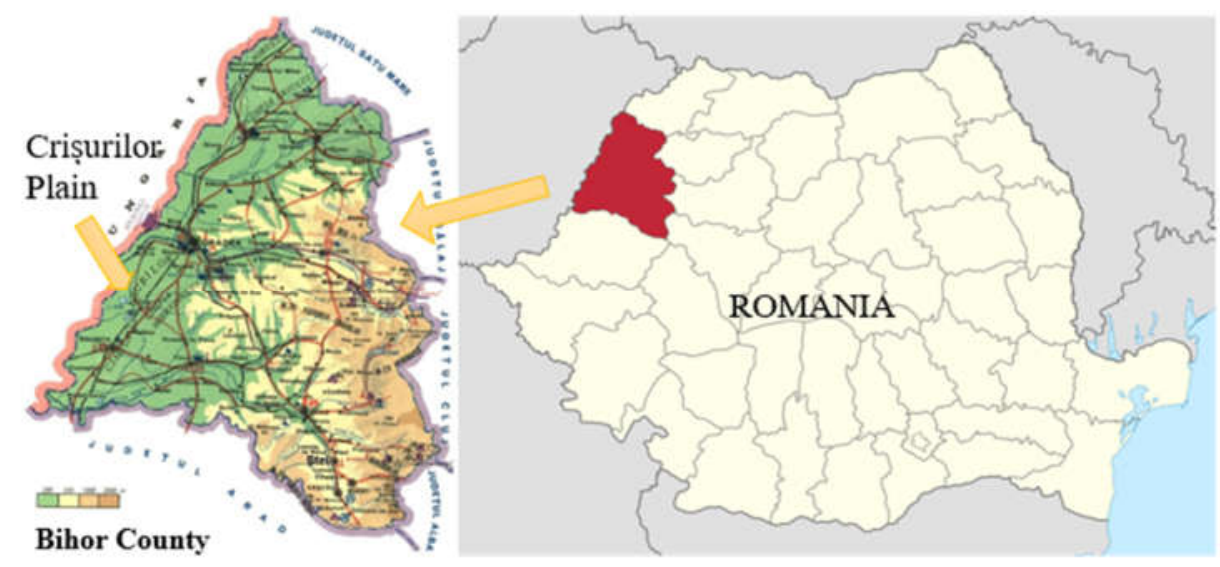
$[65,66]$

Figure 2. Location of the experimental field from Husasău de Tinca, Bihor County, Romania

To classify the climatic conditions from Husasău de Tinca, recorded data of 48 years (1970-2018) was used, (precipitation, air temperature, relative humidity, speed of wind and duration of sunlight) from the Oradea Meteorological Station located at approx. 30 Km (Table 1.) [67].

Table 1. Geographical coordinates of the Husasău de Tinca Experimental Field and of the Oradea Meteorological Station

\begin{tabular}{cccc}
\hline & Latitude & Longitude & Altitude (m) \\
\hline Husasău de Tinca & $46^{\circ} 49^{\prime} 10^{\prime} \mathrm{N}$ & $21^{\circ} 54^{\prime} 39^{\prime} \mathrm{E}$ & 134 \\
\hline
\end{tabular}




\section{Oradea}

$47^{\circ} 02^{\prime} 20^{\prime} \mathrm{N}$

$21^{\circ} 53^{\prime} 58^{\prime \prime} \mathrm{E}$

132

From an agricultural point of view, this period is defined by average rainfall values of $620.0 \mathrm{~mm}$, with a variation range between $411.0 \mathrm{~mm}$ and $889.8 \mathrm{~mm}$ and respectively average air temperature values of $10.7^{\circ} \mathrm{C}$, with a minimum of $8.9^{\circ} \mathrm{C}$ and a maximum of $12.45^{\circ} \mathrm{C}$. (Table 2.) In order to assess the suitability of using PV for SPAPV supply, it should be noted that the average number of sunny days is 296.56 and the average annual sunshine duration is 2104.43 hours.

Table 2. Climatic data - average values of the agricultural years (Oct-Sept) at the Oradea Meteorological Station (1970-2018)

\begin{tabular}{lcccccc}
\hline Climatic data & $\begin{array}{c}\text { Number of } \\
\text { agricultural } \\
\text { years }\end{array}$ & MEAN & MIN & MAX & STDEV $^{*}$ & MSE** \\
\hline Rainfall $(\mathrm{mm})$ & 48 & 620.0 & 411.0 & 889.8 & 120.3 & 17.4 \\
\hline Air temperature $\left({ }^{\circ} \mathrm{C}\right)$ & 48 & 10.70 & 8.90 & 12.45 & 1.23 & 0.03 \\
\hline Relative humidity $(\%)$ & 48 & 76.68 & 67.50 & 83.58 & 3.61 & 0.52 \\
\hline Speed of wind $\left(\mathrm{ms}^{-1}\right)$ & 48 & 2.93 & 2.40 & 3.60 & 0.30 & 0.04 \\
\hline Number of sunny days & 48 & 296.56 & 271.00 & 321.00 & 10.88 & 1.57 \\
\hline $\begin{array}{l}\text { Duration of sunlight } \\
\text { (hours) }\end{array}$ & 48 & 2104.43 & 1814.4 & 2535.2 & 139.24 & 20.1 \\
\hline
\end{tabular}

* STDEV - Standard deviation; ${ }^{* *}$ MSE - Mean square error

In solariums, the soil type is a Haplic Luvosoil one, with an average colloidal clay content $(<0.002 \mathrm{~mm})$ on the watering depth of $50 \mathrm{~cm}$ is $34.2 \%$, a bulk density (BD) of 1.48 $\mathrm{g} \mathrm{cm}^{-3}$, a field capacity (FC) of $24.0 \%$ and a wilting coefficient (WC) of $9.7 \%$.

For the two variants of tomato, one cultivated without mulching (WM) and one mulched with black foil (MBF), the watering norm was $275 \mathrm{~m}^{3} \mathrm{ha}^{-1}$ and $245 \mathrm{~m}^{3} \mathrm{ha}^{-1}$, respectively. In the first case, the distribution of water to the plant is made with T-type drippers, while in the second one is made with microtubes. (Figure 3.)

The experimental field, in which organic tomatoes were grown in solariums in $\mathrm{Hu}-$ sasău de Tinca, was arranged in subdivided blocks, with two variants (WM and MBF) in 4 random repetitions. Considering that the placement of the repetition plots was in Latin square, the yields obtained in the period 2015-2017 were statistically processed using the appropriate methodology and the Excel program [68]. The yields differences of the studied variants, were made with the Fischer test $(\mathrm{F})$ and the Student test $(\mathrm{t})$, in order to establish the statistical significance.

2.2. Water consumption of tomatoes grown in solariums in Husasău de Tinca

For the design of the SPAPV to provide drip irrigation of the four solariums, it is necessary to determine the need for water, starting with determination of the ET of tomatoes grown indoors. 

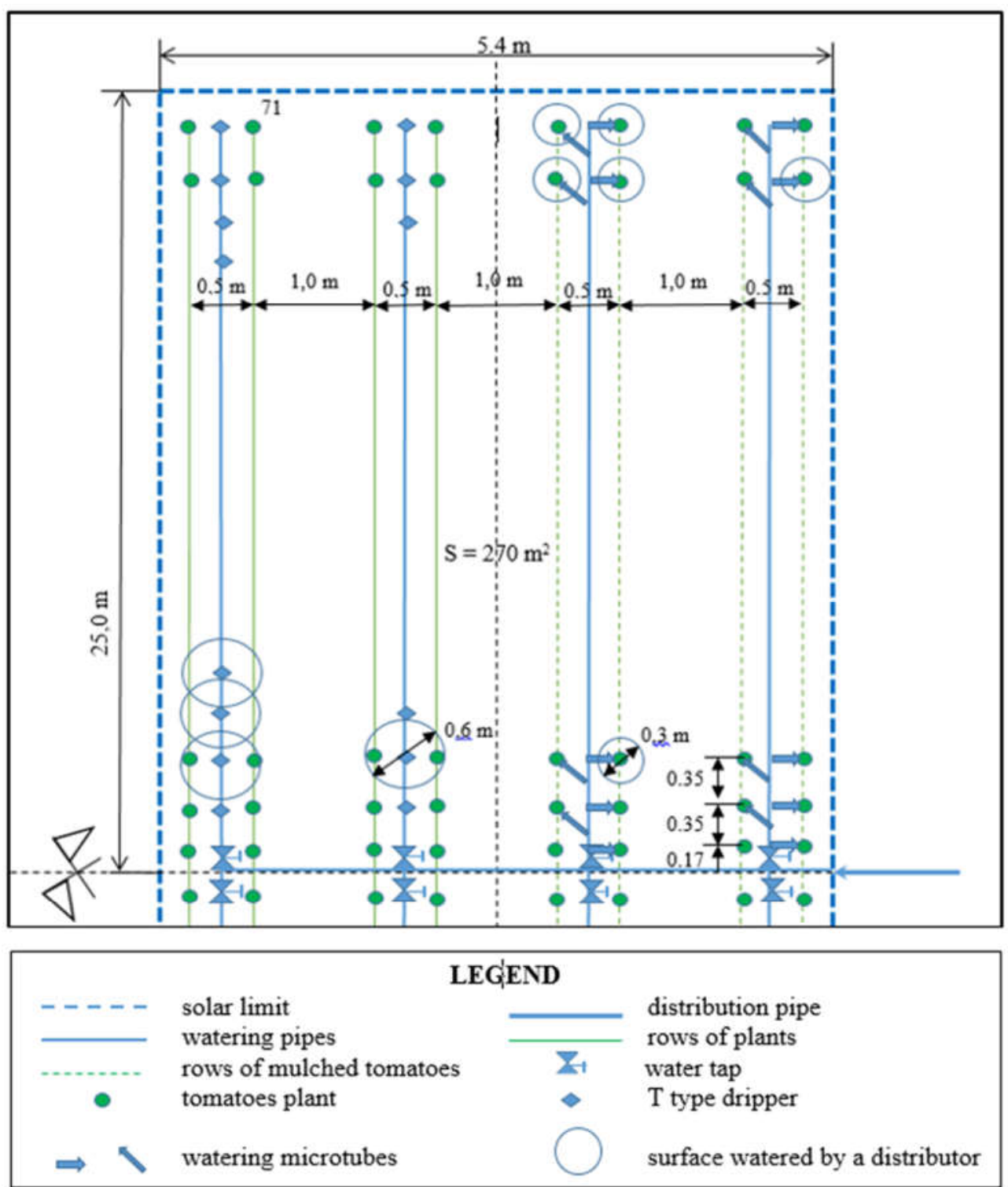

Figure 3. Water distribution of tomato variant located in Husasău de Tinca solariums

To determine the water consumption of tomatoes grown indoors, we used indoor temperatures, recorded in the growing season, from the year in which was a $20 \%$ assurance of exceeding the air temperature. The agricultural year for which the average outside temperature, of vegetation period (Apr-Sep), exceeds the insurance of $20 \%$ was established using the data recorded at the Oradea Meteorological Station in the period 19702018. The Pearson type III function [69] was used to determine the probability of exceeding the air temperature, having the relation (1):

Where:

$$
\varphi(\mathrm{u})=\mathrm{A} \cdot \mathrm{u} \cdot e^{a-u} ;
$$

$$
\mathrm{u}=-\frac{\mathrm{x}}{2 \cdot \sigma^{2}} ; \text { and } \mathrm{A}=\frac{1}{2 \cdot \sigma^{2} \cdot \Gamma_{(\mathrm{a}+1)}} \text {; }
$$

In which:

$x$ - the value of a series of observations for which the probability is to be determined; $\mathrm{e}$ - the basis of natural logarithms;

a - function parameter; 
$\sigma$ - the mean square deviation of all the values of the studied event;

$\Gamma(a+1)$ - Euler integral (second case) or Gama function;The probability of exceeding a value $x_{i}$ from a string $x_{1}, x_{2} \ldots . x_{n}$ is obtained by integrating the curve given by the considered function, on the interval $\mathrm{x}_{1}-+\infty$ (3):

$$
\mathrm{P}=\int_{\mathrm{x}_{1}}^{\infty} \varphi(\mathrm{x}) \mathrm{dx}
$$

In which:

P - Probability of exceeding the value $\mathrm{x}_{\mathrm{i}}$;

$\varphi(x)$ - the function that describes the evolution of event $x$ for the observation period; After the sequence of average values of the air temperature in the warm season of each agricultural year : $x 1, x 2 \ldots x n$, has been ordered in descending order, we have calculated for each value the probability $\mathrm{P}(\%)$ using the relation (4):

$$
\mathrm{P}(\%)=\frac{\mathrm{i}}{\mathrm{n}+1} \cdot 100
$$

Where:

$i$ - the sequence number of the $x_{i}$ value, in the descending sequence;

$\mathrm{n}$ - the total number of values $(\mathrm{xn})$ of the analyzed string;

From this table was chosen the agricultural year and respectively the average temperature of warm season, corresponding to the insurance of exceeding $20 \%$.

Considering the average monthly values, from the vegetation period, with the assurance of $20 \%$ as external values (Ta) of the solariums from Husasău de Tinca, these were transformed into internal temperatures (Ti), using the correlative link (5) established by previous researches [64].

$$
\mathrm{T}_{\mathrm{i}}=0.8796 \cdot \mathrm{Ta}+6.281
$$

Where:

$\mathrm{T}_{\mathrm{i}}$ - Average monthly temperature inside solariums $\left({ }^{\circ} \mathrm{C}\right)$;

$\mathrm{T}_{\mathrm{a}}$ - The average monthly temperature, outside the solariums, determined in Oradea, with the insurance of $20 \%\left({ }^{\circ} \mathrm{C}\right)$;

With their help, the potential evapotranspiration (PET) was determined using the relation Thornthwaite (6) and the DrinC program 70, 71].

$$
\mathrm{PET}=1.6 \cdot\left(\frac{10 \cdot \mathrm{t}}{\mathrm{I}}\right)^{\mathrm{a}} \cdot \mathrm{K}
$$

Where:

PET - the potential evapotranspiration $(\mathrm{cm})$;

$\mathrm{t}$ - average inside temperature of the month from vegetation period $\left({ }^{\circ} \mathrm{C}\right)$;

I - annual heat index, calculated as the sum of the 12 monthly indices i (7):

$$
\mathrm{I}=\sum_{1}^{12} \mathrm{i} ; \quad \mathrm{i}=\left(\frac{\mathrm{t}_{\mathrm{n}}}{5}\right)^{1.541} ;
$$

* monthly indices are calculated only for positive temperature.

$\mathrm{t}_{\mathrm{n}}$ - normal monthly average temperature $\left({ }^{\circ} \mathrm{C}\right)$;

a - an empirical coefficient, determined by the relation (8):

$$
\mathrm{a}=0.000000675 \cdot \mathrm{I}^{3}-0.000771 \cdot \mathrm{I}^{2}+0.01792 \cdot \mathrm{I}+0.49239 ;
$$

$\mathrm{K}$ - monthly PET correction coefficient according to the length of the day, determined according to the latitude of the considered area.

In order to obtain the monthly water requirement of tomatoes grown in solariums (ETRo), the calculated PET data, must be converted using the correction coefficients, specific to the crop considered [72]. The culture coefficients Kc, for the tomatoes grown in solarium at Husasău de Tinca, were determined experimentally, both for the WM variant and for the MBF variant [63].

\subsection{Irrigation regime of tomatoes grown in solariums in Husasău de Tinca}


The watering norm $(\mathrm{m})$ represents the amount of water administered by irrigation of one hectare of a certain crop. The amount of water administered during one watering depends on the hydrophysical characteristics of the soil, respectively on the water storage capacity in the soil. The relationship used to determine the watering rate $(\mathrm{m})$ when drip irrigation (9), takes into account that the moistened surface is reduced compared to sprinkler watering, due to the fact that, only the root area of the plants is moistened [64, 73].

$$
m=\frac{100 \cdot H \cdot B D(F C-W C)}{\eta} \cdot y \cdot \frac{P}{100}
$$

Where:

$\mathrm{m}$ - norm of water application by drip irrigation $\left(\mathrm{m}^{3} \mathrm{ha}^{-1}\right)$

$\mathrm{H}$ - depth of soil wetting $(\mathrm{m})$;

$\mathrm{BD}$ - volumetric weight or bulk density of the soil $\left(\mathrm{tm}^{-3}\right.$ or $\left.\mathrm{gcm}^{-3}\right)$;

FC - field capacity for water of the soil (\%);

WC - wilting coefficient (\%);

$\mathrm{y}$ - the fraction in the range of available moisture content (FC-WC) to be filled with water (easily accessible water between FC and MMC - minimum moisture content for watering);

$\mathrm{P}$ - the percentage of soil surface actually moistened;

$\eta$ - the efficiency of the uniformity of the watering along the watering pipe $(0.8-0.9)$ Considering that the density is 5.7 plants $/ \mathrm{m}^{2}$, and the distribution of water per plant, for the WM variant, is done with T-type tubes, the percentage of moistened surface being 43.6 $\%$ and for MBF variant, with microtubes, the percentage being $40.5 \%$.

The irrigation regime during the vegetation period of the tomatoes establishes, starting from the watering norm $\mathrm{m}$, the number of waterings necessary in each month, to cover their optimal consumption [30,74]. To determine when to apply a new watering we started from the assumption that the initial water reserve in the soil at the beginning of the vegetation period (May 1) is halfway through the active humidity range, which is the difference between field capacity (FC) and minimum ceiling (MC). Knowing the average monthly daily consumption of tomatoes, it is established when the soil moisture reaches the $\mathrm{MC}$ and it is necessary to supplement the soil moisture by applying a new watering norm. This hypothesis, in field conditions, is satisfied in rainy springs, but in solar conditions, in order to ensure soil moisture at planting, a supply watering is applied outside the vegetation period.

\subsection{Design of SPAPV from tomatoes grown in solariums at Husasău de Tinca}

The main characteristics required for the design of water PS are the pumped flow and the required pressure in the pipes [75]. Hydraulic pressure losses or pressure losses are the energy lost by the water when passing through the pipes due to friction with them. Their knowledge is important to determine the pumping height, at discharge, necessary for the proper functioning of the drippers [76]. When estimating the pressure losses, variants of SPAPV arrangement were simulated, using direct pumping (ADP) of water (Figure 4.a.) and with gravitational distribution using a water storage tank (ATS). (Figure 4.b.) The solar pump (SP) used must provide a pressure of 0.2 bar, ie $2 \mathrm{~m}$ of water column (MWC) required for the operation of the drippers. Given that the water source is a surface one, to this is added the suction height of $1.0 \mathrm{~m}$ and the hydraulic load losses on the transport and local pipes, estimated at approx. 1.0 MWC. Therefore, for our conditions, an SP with a DC motor is required to ensure a pumping height of at least $4 \mathrm{MWC}$. An SP that provides this pressure, can also pump water into the compensation tank, located on a support, at a minimum height of $2.5 \mathrm{~m}$. Considering that most SPs are depth pumps, designed to pump water from boreholes, have high pumping heights but with low pumping flows, several offers of the most well-known manufacturer of SPs, the German company Lorentz, were analyzed. (Table 3.) 


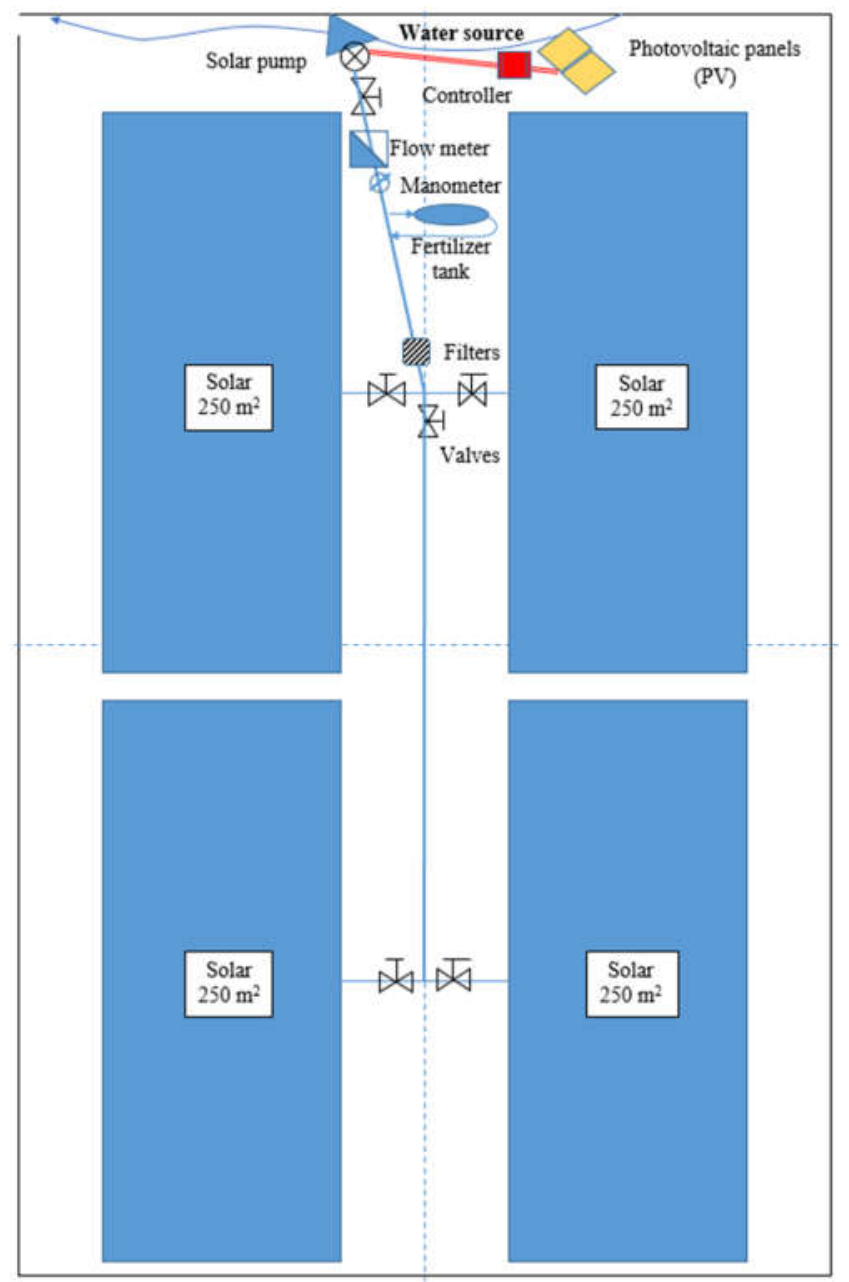

(a)

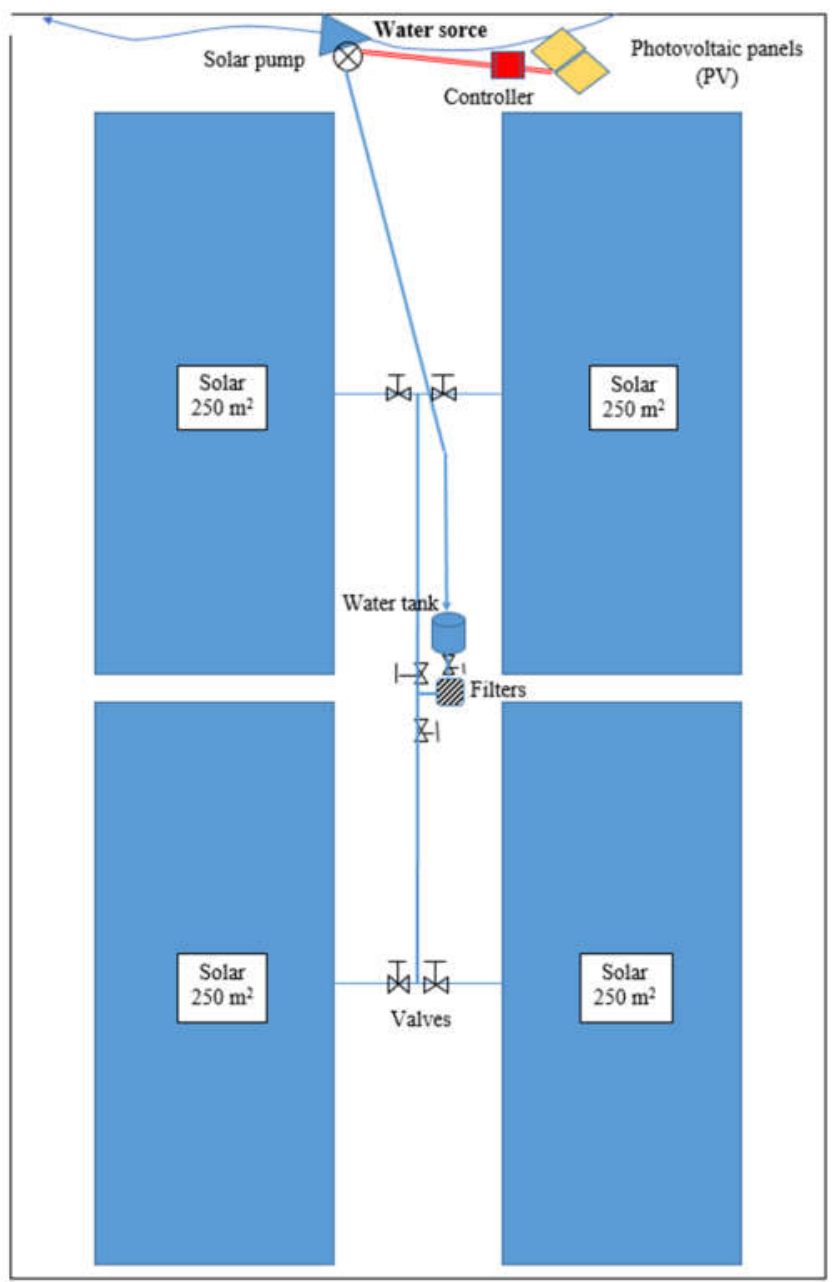

(b)

Figure 4. Arrangements for localized irrigation of solariums: $a$ - with direct pumping (ADP); $b$ with water storage tank (ATS)

Table 3. Variants of solar pumps produced by Lorentz

\begin{tabular}{cccccc}
\hline Manufacturer & Type & $\begin{array}{c}\text { Pumping } \\
\text { height } \\
\text { (MWC) }\end{array}$ & $\begin{array}{c}\text { Debit } \\
\left(\mathbf{m}^{\mathbf{3}} \mathbf{h} \mathbf{- 1}\right)\end{array}$ & $\begin{array}{c}\text { Rated } \\
\text { power } \\
(\mathbf{k W})\end{array}$ & Reference \\
\hline Lorentz & PS 2-600CS-17-1 & 12 & 18 & 0.7 & {$[77]$} \\
Lorentz & PS2-1800CS-37-1 & 14 & 36 & 1.8 & {$[77]$} \\
Lorentz & PS-150 BOOST-330 & 50 & 1.3 & 0.3 & $77]$ \\
Lorentz & PS600 BADU Top12 & $\mathbf{4}$ & $\mathbf{1 0}$ & $\mathbf{0 . 5}$ & {$[78]$} \\
\hline
\end{tabular}

Among the SP variants analyzed, the PS600 BADU Top12 pump is chosen, which has the lowest pumping height and which is delivered together with the PS 600 controller. The SP is driven by an ECDRIVE 600 BADU Top DC motor, driven by the current produced by solar panels (340-900 Wp) via an controller. (Figure 5.) The water flow pumped during different periods of the growing season was estimated using the characteristic flow curve of the chosen pump with power supply $(\mathrm{W})$ and the required pumping height. (Figure 6.) 


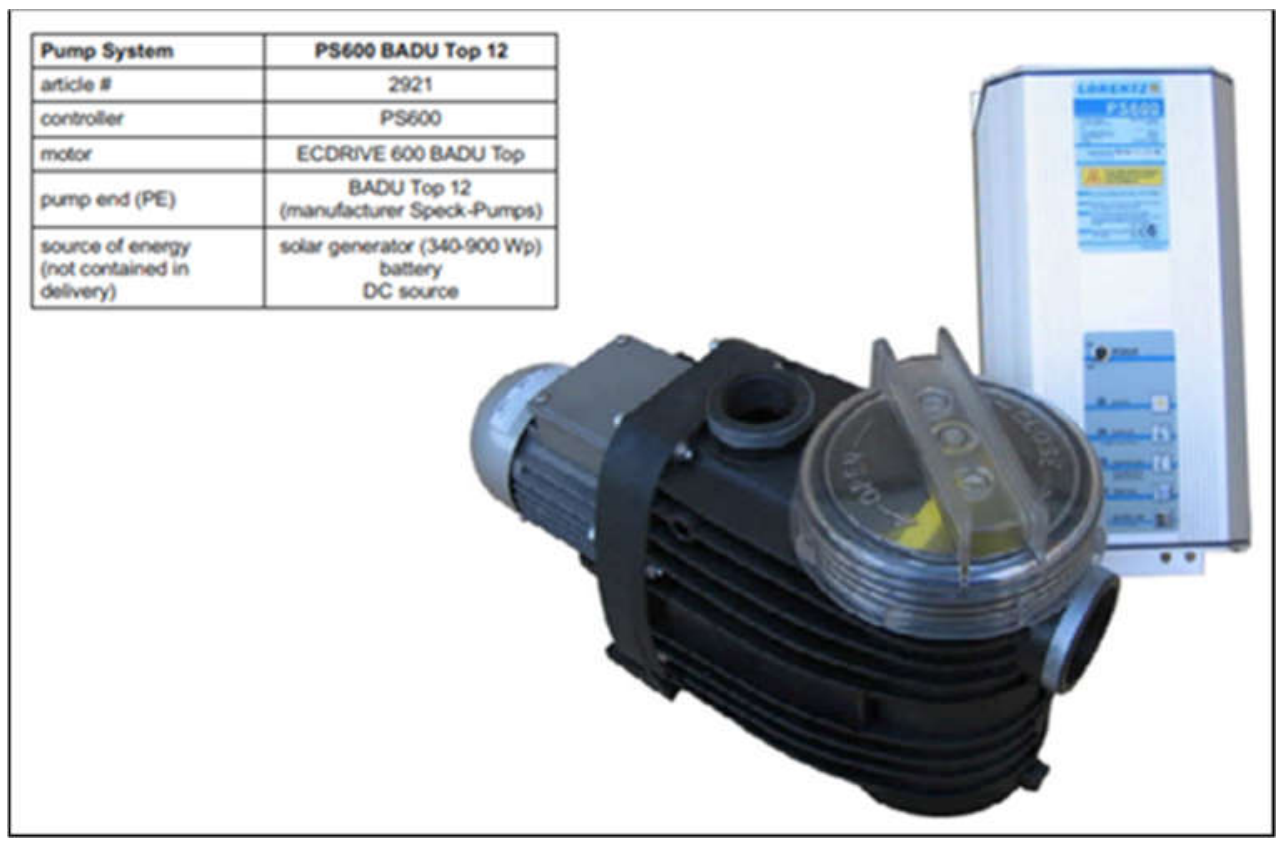

Figure 5. Technical characteristics of the SP PS600 BADU top 12 [78]

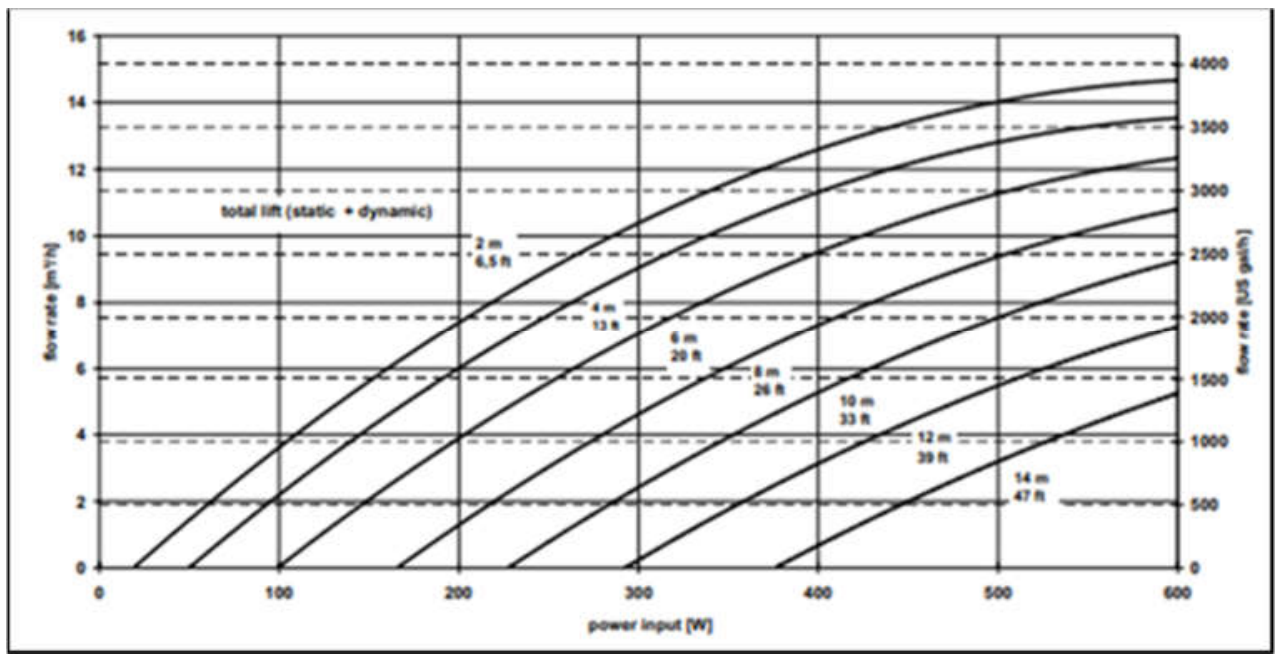

Figure 6. Flow characteristic curve - input power and required pumping height [78]

The Angstrom-Prescott equation (10), was used to estimate the average daily global solar radiation $\mathrm{H}\left(\mathrm{Whm}^{-2}\right)$, with the following form [79]:

Where:

$$
\mathrm{H}=\mathrm{Ho}(0.2881+0.7429 \sigma 0.6168) \text {; }
$$

Ho is solar irradiation in clear sky conditions;

$\sigma$ is the relative daily duration of sunshine;

The monthly values of horizontal and inclined global solar irradiation at $45^{\circ}$, for $\mathrm{Hu}-$ sasău de Tinca, Crișurilor Plain, were estimated using PVGIS-5 temporal irradiation dabase [80]. To determine the average daily and hourly values were used: the number of days (monthly and annually) with sun, the duration of sunshine in hours (monthly and annual amounts), the duration of the solar day, in hours [81], registered at the Oradea Meteorological Station, Bihor County.

Photovoltaic panels (PV) were chosen from a wide range of types and features on the market. 5 types of PV produced in countries with a tradition in this field were analyzed. (Table 4.) 
Table 4. Variants of photovoltaic panels (PV).

\begin{tabular}{|c|c|c|c|c|c|c|}
\hline Trade name & Manufacturer & Type* & $\begin{array}{c}\text { Surface } \\
\left(\mathrm{m}^{2}\right)\end{array}$ & $\begin{array}{l}\text { Power } \\
\text { (W) }\end{array}$ & $\begin{array}{c}\text { Efficiency } \\
(\%)\end{array}$ & Source \\
\hline SPM041751200 & $\begin{array}{l}\text { Victorian Energy, } \\
\text { Netherlands }\end{array}$ & M & 0.99 & 175 & 13.0 & [82] \\
\hline TM-P660265 & Tamesol, Spain & $\mathrm{P}$ & 1.46 & 265 & 14.4 & [83] \\
\hline SGSP-150 & Sun Power, USA & M & 0.78 & 150 & 22.6 & [84] \\
\hline FVG-185M-MC & FVG Energy, Italy & M & 1.28 & 185 & 14.5 & [85] \\
\hline AE320M6-60 & AE Solar, Germany & $\mathbf{M}$ & 1.66 & 320 & 19.3 & [86] \\
\hline
\end{tabular}

* M - Monocrystalline; P - Polycrystalline

The AE320M6-60 PV, produced in Germany, was preferred due to the high power supplied, $320 \mathrm{~W}$ at a good efficiency of $19.3 \%$.

2.5. Effectiveness of measures to reduce the effects of climate change and energy consumption.

For the evaluation of the economic efficiency of the SPAPVs, for the two possibilities of arrangement for drip irrigation: with direct pumping (ADP) and gravitational, with water storage tank (ATS); the Specific Investment (SI) was determined. SI represents the cost of arranging one hectare of land for drip irrigation, including: the cost of materials (SP, controller, PVs, pipes, valves, manometers, fertilizer tank, filters, water storage tank) labor (cost of construction work) and possibly the rates owed to the bank for the loan.

The investment payback time (IPT) represents the number of years in which the expenses with the arrangement of the two types of arrangement for drip irrigation (ADP and ATS) are recovered by the annual net profit (ANP) obtained, as a result of capitalizing the obtained yield. To determine the IPT expressed in years, the relation (11) was used $[87,88]$ :

$$
\mathrm{IPT}(\text { years })=\frac{\mathrm{SI}}{\mathrm{ANP}}
$$

ANP represents the difference between the income realized by capitalizing the annual yield (IY) and the production expenses (PE), represented by materials (seeds, black foil, treatments, etc.), salaries, taxes and duties.

$$
\mathrm{ANP}=\mathrm{IY}-\mathrm{PE} \text {; }
$$

The annual yield of certified organic tomatoes, sorted by 2 quality categories were capitalized on the agri-food market in Oradea.

For the calculation of the irrigation water use indices, Water Use Coefficient (WUC), Water Use Efficiency (WUE), Irrigation Water Use Coefficient (IWUC) and Irrigation Water Use (IWUE) the relations were used $[61,64,89,90]$. WUC is the ratio of water consumption (ETRo) to crop yield (Y) expressed in $\mathrm{m}^{3} \mathrm{~kg}^{-1}$ :

$$
\mathrm{WUC}=\frac{\text { ETRo }}{\mathrm{Y}}
$$

WUE $\left(\mathrm{kg} \mathrm{m}^{-3}\right)$ is the inverse ratio of WUC, given by the crop yield for the unit of water consumed:

$$
\mathrm{WUE}=\frac{\mathrm{Y}}{\mathrm{ETRo}}
$$

IWUC and IWUE are the ratios between the irrigation norm $(\Sigma \mathrm{m})$, during the growing season and the increase yield (IY), brought about by the application of irrigation.

$$
\text { IWUC }=\frac{\sum \mathrm{m}}{\mathrm{IY}} \text { and IWUE }=\frac{\mathrm{IY}}{\sum \mathrm{m}}
$$

Because in our case, we do not have yields of tomatoes, for the version without irrigation, and the yield increases cannot be calculated, for the calculation of IWUC and IWUE the yields $(Y)$ from the irrigated variants were used. 


\section{Results}

\subsection{Irrigation regime of tomatoes grown in solariums}

The agricultural year with the average air temperature $(12.2 \circ \mathrm{C})$ having the insurance of exceeding $20 \%$, at the Oradea Meteorological Station was 2015 - 2016. For the vegetation period of tomatoes grown in solariums, the average air temperature was $18.8{ }^{\circ} \mathrm{C}$, while inside solariums it was $22.8^{\circ} \mathrm{C}$. PET has monthly values between $75.31 \mathrm{~mm}$ in April and $171.46 \mathrm{~mm}$ in July. (Table 5.)

Table 5. Water consumption of tomatoes (ETRo) grown in solariums in Husasău de Tinca, during the vegetation period of the agricultural year 2015 - 2016

\begin{tabular}{|c|c|c|c|c|c|c|c|c|}
\hline \multirow{2}{*}{ Specification } & \multirow{2}{*}{ U.M. } & \multicolumn{6}{|c|}{ Vegetation period } & \multirow{2}{*}{$\begin{array}{l}\text { Average } \\
\text { Sum }\end{array}$} \\
\hline & & Apr & May & Jun & Jul & Aug & Sep & \\
\hline Air temperature Oradea (Ta) & ${ }^{\circ} \mathrm{C}$ & 13.4 & 16.4 & 21.3 & 22.5 & 21.1 & 18.0 & 18.8 \\
\hline Air temperature inside solarium $(\mathrm{Ti})$ & ${ }^{\circ} \mathrm{C}$ & 18.1 & 20.7 & 25.0 & 26.1 & 24.8 & 22.1 & 22.8 \\
\hline \multirow{2}{*}{ Potential Evapotranspiration inside solarium (PE } & $\begin{array}{c}\mathrm{mm} \\
\text { month }^{-1}\end{array}$ & 75.31 & 110.37 & 157.73 & 171.46 & 143.80 & 99.34 & 7580.01 \\
\hline & $\mathrm{m}^{3} \mathrm{ha}^{-1}$ & 753.1 & 1103.7 & 1577.3 & 1714.6 & 1438.0 & 993.4 & 75800.1 \\
\hline $\begin{array}{l}\text { The culture coefficient }(\mathrm{Kc}) \\
\text { WM variant }\end{array}$ & & 1.01 & 1.03 & 1.02 & 1.03 & 0.77 & 0.57 & 0.819 \\
\hline $\begin{array}{l}\text { The culture coefficient }(\mathrm{Kc}) \\
\text { MBF variant }\end{array}$ & & 1.00 & 1.02 & 1.00 & 0.96 & 0.72 & 0.55 & 0.875 \\
\hline \multirow{3}{*}{$\begin{array}{l}\text { Optimal actual evapotranspiration (ETRo) } \\
\text { WM variant }\end{array}$} & $\mathrm{m}^{3} \mathrm{ha}^{-1}$ & 760.6 & 1136.8 & 1608.8 & 1766.0 & 1107.3 & 566.2 & 6945.7 \\
\hline & $\begin{array}{c}\mathrm{m}^{3} \text { ha }^{-1} \\
\text { day }^{-1}\end{array}$ & 25.35 & 36.67 & 53.63 & 46.97 & 35.72 & 18.87 & 217.21 \\
\hline & $\begin{array}{c}\text { mm } \\
\text { day }^{-1}\end{array}$ & 25.4 & 36.7 & 53.6 & 47.0 & 35.7 & 18.9 & 217.3 \\
\hline \multirow{3}{*}{$\begin{array}{l}\text { Optimal actual evapotranspiration (ETRo) } \\
\text { MBF variant }\end{array}$} & $\mathrm{m}^{3} \mathrm{ha}^{-1}$ & 753.1 & 1125.8 & 1577.3 & 1646.0 & 1035.4 & 546.4 & 6594.0 \\
\hline & $\begin{array}{c}\text { m }^{3} \text { ha }^{-1} \\
\text { day }^{-1} \\
\end{array}$ & 25.10 & 36.32 & 52.28 & 53.10 & 33.40 & 18.21 & 215.41 \\
\hline & $\begin{array}{l}\mathrm{mm} \\
\text { day }^{-1}\end{array}$ & 25.1 & 36.3 & 52.6 & 53.1 & 33.4 & 18.2 & 218.7 \\
\hline
\end{tabular}

ETRo for the WM variant indicates a water consumption of $6945.7 \mathrm{~m}^{3} \mathrm{ha}^{-1}$, higher than the MBF variant with a consumption of $6594.0 \mathrm{~m}^{3} \mathrm{ha}^{-1}$. The average daily consumptions of the two variants are very close, having values between $25.4-53.6 \mathrm{~mm}^{-1 a y^{-1}}$ for WM and respectively $25.1-53.1 \mathrm{~mm} \mathrm{day}^{-1}$ for MBF. The amount of water that can be administered at a watering (watering norm $\mathrm{m}$ ), on the depth of $50 \mathrm{~cm}$ of the soil and the surface actually watered, without exceeding the water storage capacity in the soil is $182 \mathrm{~m}^{3} / \mathrm{ha}$ for the WM variant and $169 \mathrm{~m}^{3} /$ ha for MBF. (Table 6.)

For the same water storage conditions in the soil, the lower values of $\mathrm{m}$, corresponding to the MBF variant, are due to the lower percentage of wetland than to the WM variant. Taking into account the fact that a distributor (dripper) is placed on each plant, he must administer 3.2 $\mathrm{L}_{\text {plant }}{ }^{-1}$, in the WM variant and 3.0 L plant ${ }^{-1}$ in the MBF variant, respectively. For this, the T-type tubes at a pressure of 0.4 bar, with an average flow of $1.25 \mathrm{~L} \mathrm{~h}^{-1}$, must operate for 4 hours, and the microtubes, with a flow of $0.5 \mathrm{~L} \mathrm{~h}^{-1}$, for 6 hours.

Table 6. Calculation of the watering norm $(\mathrm{m})$ 
H (m) Bulk

Den- FC- Percentage Watering

$\begin{array}{llll}\text { sity } B D & \text { MC of watered efficiency } \mathrm{m}^{3} \mathrm{ha}^{-1} & \mathrm{~L} \mathrm{~m}^{-2} & \mathrm{~L} \text { plant } \\ \end{array}$

$\left(\mathrm{g} \mathrm{cm}^{-3}\right)(\%)$ area $\mathrm{P} / 100 \quad \eta$

\begin{tabular}{ccccccccc}
\hline WM variant & 0.50 & 1.48 & 4.8 & 0.436 & 0.85 & 182 & 18.2 & 3.2 \\
\hline MBF variant & 0.50 & 1.48 & 4.8 & 0.405 & 0.85 & 182 & 16.9 & 3.0 \\
\hline
\end{tabular}

The irrigation regime of tomatoes grown in solariums differs, depending on the cultivation system practiced. The highest monthly watering norms are met in June, $1638 \mathrm{~m}^{3}$ $\mathrm{ha}^{-1}$, for the WM variant and in July, $1690 \mathrm{~m}^{3} \mathrm{ha}^{-1}$ for the MBF variant. (Figure 7.)

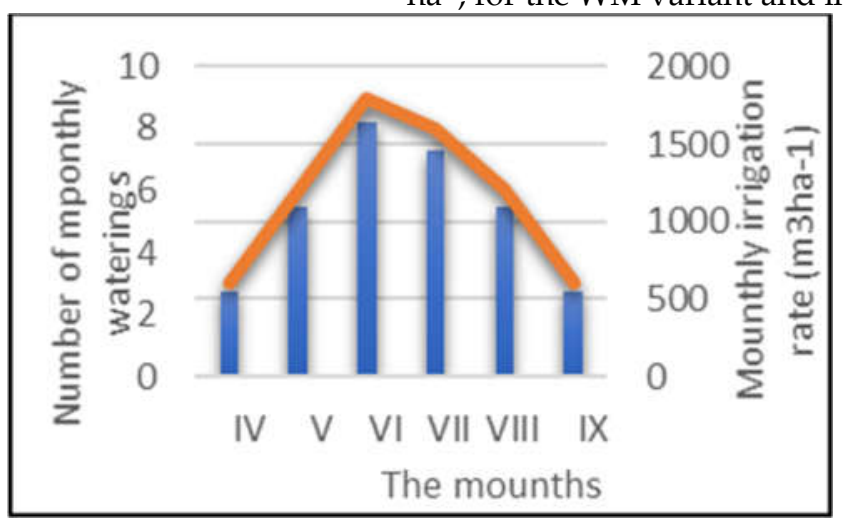

(a)

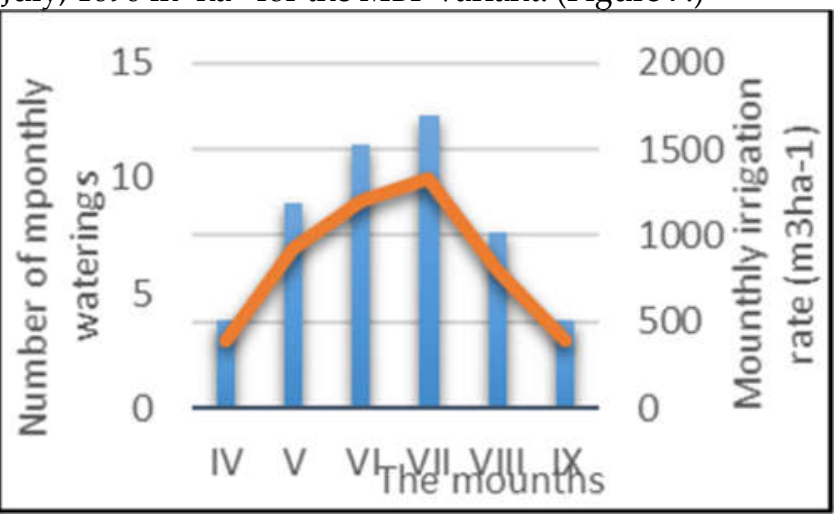

(b)

Figure 7. Irrigation regime of tomatoes grown in solariums: $a-W M ; b-M B F$;

If in the case of WM 35 waterings totaling $6370 \mathrm{~m}^{3} \mathrm{ha}^{-1}$ of water are required, for MBF, although the consumption is slightly lower, due to the fact that, the water storage capacity in the soil is lower, 38 waterings, using $6422 \mathrm{~m}^{3} \mathrm{ha}^{-1}$ are required. Analyzing the data for the application of watering, during the vegetation period of tomatoes grown in solariums, in 2016 it is noted that, in most cases the data are different for the two variants. (Table 7.)

Table 7. Watering scheduling dates for tomatoes grown in solariums

\begin{tabular}{|c|c|c|c|c|c|c|c|c|}
\hline \multirow{2}{*}{ Months } & \multicolumn{4}{|c|}{ Without mulching (WM) } & \multicolumn{4}{|c|}{ Mulched with black foil (MBF) } \\
\hline & Data & $\mathrm{n}$ & $\mathrm{m}$ & $\Sigma \mathrm{m}$ & Data & $\mathrm{n}$ & $\mathrm{m}$ & $\Sigma \mathrm{m}$ \\
\hline Apr & $14,22,29$ & 3 & 182 & 546 & $14,20,27$ & 3 & 169 & 507 \\
\hline May & $4,9,14,19,24,29$ & 6 & 182 & 1092 & $3,7,12,16,21,26,30$ & 7 & 169 & 1183 \\
\hline Jun & $\begin{array}{c}2,5,9,12,15,18,22,26 \\
30\end{array}$ & 9 & 182 & 1638 & $\begin{array}{c}3,6,9,12,16,19,22 \\
25,28\end{array}$ & 9 & 169 & 1521 \\
\hline Jul & $3,7,10,14,18,22,26,30$ & 8 & 182 & 1456 & $\begin{array}{c}2,5,8,11,14,17,21, \\
24,27,30\end{array}$ & 10 & 169 & 1690 \\
\hline Aug & $4,9,14,19,24,29$ & 6 & 182 & 1092 & $4,9,14,19,24,29$ & 6 & 169 & 1014 \\
\hline Sep & $7,16,26$ & 3 & 182 & 546 & $7,16,25$ & 3 & 169 & 507 \\
\hline TOTAL & & 35 & & 6370 & & 38 & & 6422 \\
\hline
\end{tabular}

From the point of view of the number of waterings required in a month, it is observed that in July, 8 waterings are required for the WM version, while 10 waterings are required for the MBF version. The average return time with a watering on the same surface is in the first case 3.9 days and in the second case 3.1 days.

3.2. The main characteristics of SPAPV from tomatoes grown in solariums

Horizontal global solar irradiation in calendar year 2016 to Husasău Tinca is 1319.1 $\mathrm{kWh} \mathrm{m}{ }^{-2}$ with a maximum value estimated in July $\left(189.8 \mathrm{kWh} \mathrm{m}^{-2}\right)$ and tilt to $45^{\circ}$ of 1641.4 
kWh m-2, monthly maximum being $196.16 \mathrm{kWh} \mathrm{m}^{-2}$ being estimated in August. (Figure 8.) For the vegetation period of tomatoes grown in solariums (Apr - Sep) the horizontal solar irradiation accumulates $1005.3 \mathrm{kWh} \mathrm{m}^{-2}$, while in the case of PV inclined at $45^{\circ}$ it is estimated $1038.9 \mathrm{kWh} \mathrm{m}^{-2}$. (Table 8.)

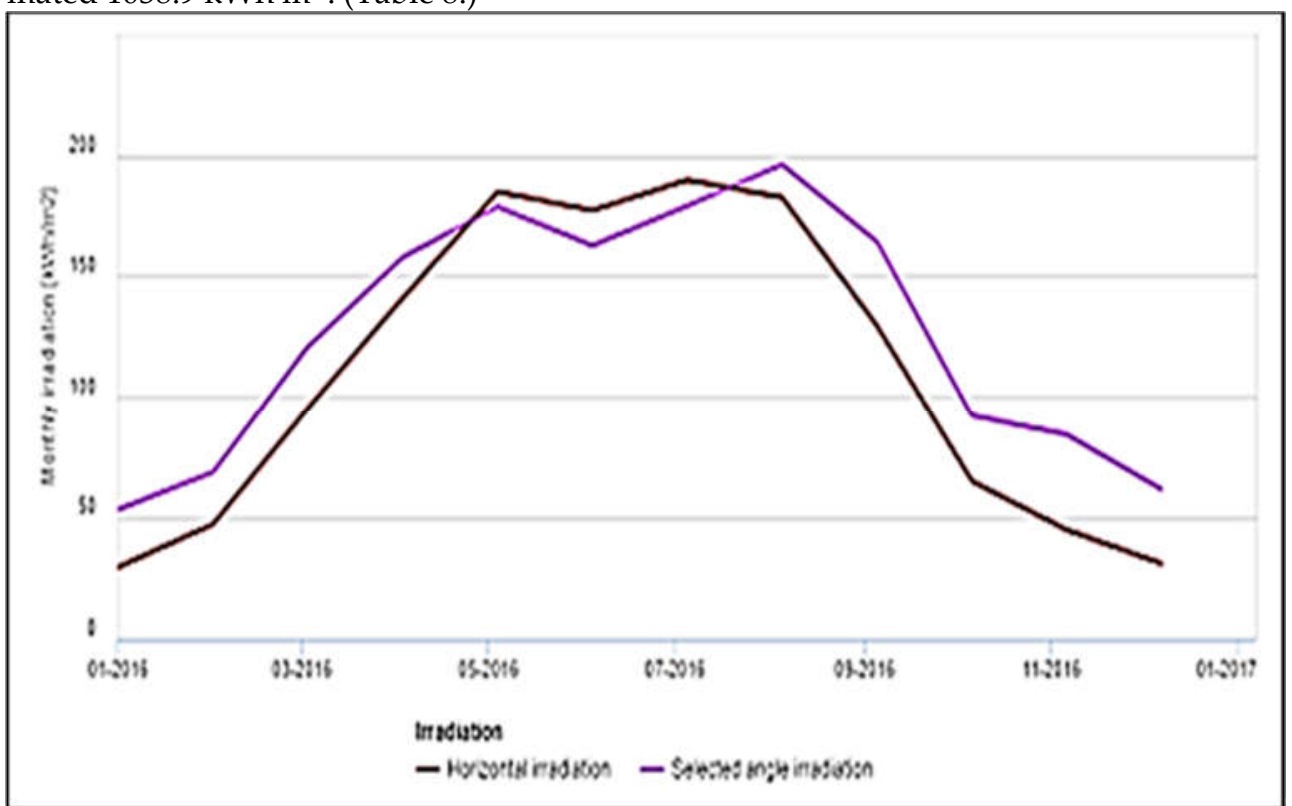

Figure 8. Estimation of monthly solar irradiation (global horizontal irradiation) for $\mathrm{Hu}$ sasău de Tinca, Romania, 2016 [82]

Table 8. Average global solar irradiation at $45^{\circ}$, Oradea Meteorological Station, 2016

\begin{tabular}{|c|c|c|c|c|c|c|c|c|}
\hline Specification & Apr & May & Jun & Jul & Aug & Sep & $\begin{array}{c}\text { Warm } \\
\text { season }\end{array}$ & Annual \\
\hline Monthly solar irradiation - H $\left(\mathrm{kWh} \mathrm{m}^{-2}\right)$ & 157.9 & 178.7 & 162.7 & 162.9 & 196.2 & 164.3 & 1038.9 & 1641.4 \\
\hline Daily solar irradiation $-\left(\mathrm{kWh} \mathrm{m}^{-2}\right)$ & 5.263 & 5.765 & 5.423 & 5.777 & 6.213 & 5.477 & 5.677 & 4.485 \\
\hline Solar day (hours) & 13.70 & 8.54 & 8.17 & 9.82 & 9.87 & 7.70 & 8.62 & 7.07 \\
\hline Average duration of sunlight (hours) & 7.36 & 8.54 & 8.17 & 9.82 & 9.87 & 7.70 & 8.62 & 7.07 \\
\hline Hourly global solar irradiation $-\mathrm{H}\left(\mathrm{W} \mathrm{m}^{-2}\right)$ & 384.2 & 380.8 & 342.4 & 372.7 & 438.2 & 435.4 & 391.8 & 365.2 \\
\hline
\end{tabular}

The average hourly value, calculated using the duration of the solar day in the vegetation period is $391.8 \mathrm{~W} \mathrm{~m}^{-2}$, with monthly values between $342.4 \mathrm{~W} \mathrm{~m}^{-2}$, in June and $438.2 \mathrm{~W} \mathrm{~m}^{-2}$ in August.

For the power supply of the SP was preferred, imposing by its technical characteristics, the PV produced in Germany, AE320M6-60. Ideally, two panels could provide $640 \mathrm{~W}$ of power, sufficient for SP operation. Given the efficiency of transformation of solar irradiation into electricity and the characteristics of SP, which indicates the need for a peak power (Wp) over $340 \mathrm{~W}$, the need for PV was determined. (Figure 9.)

Due to the fact that, for the power supply of SP the number of solar panels must be a multiple of two, it was concluded that $4 \mathrm{PVs}$ are required, mounted inclined at $45^{\circ}$, which produce over $438.8 \mathrm{Wh}$. The annual average of the produced electricity is $468 \mathrm{~W}$, and that of the vegetation season is $502 \mathrm{~W}$. 


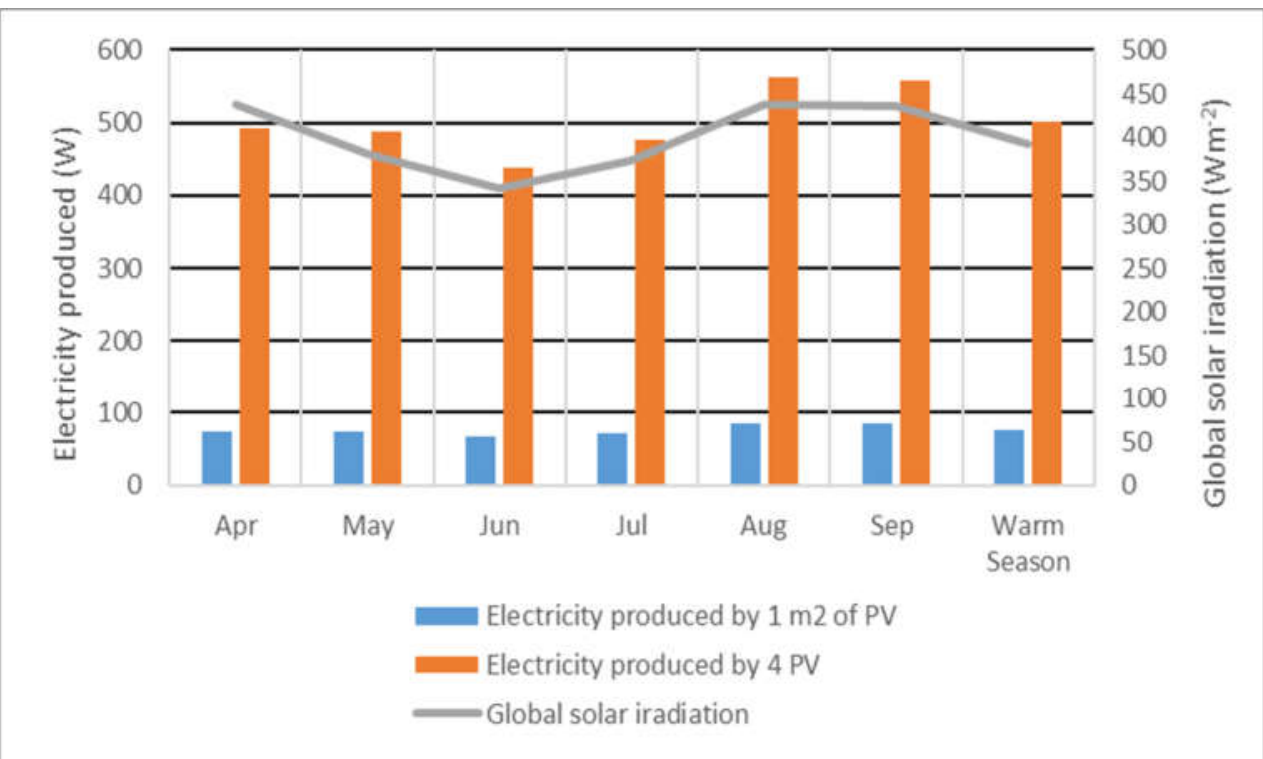

Figure 9. The PVs need for the operation of SP

The PS600 BADU Top12 solar pump, produced by Lorentz, was chosen to equip the SPSAV, which provides an average flow rate of $10 \mathrm{~m}^{3} \mathrm{~h}^{-1}$ at a maximum pumping height of $4 \mathrm{~m}$. According to the characteristic curve of the SP, it is noted that, in the conditions of a lower pumping height and a supplied power greater than about $350 \mathrm{~W}$, the supplied flow can increase up to $13.7-13.8 \mathrm{~m}^{3} \mathrm{~h}^{-1}$. The water flow pumped by SPAPV is an average daily value, due to the fact that, it was appreciated with the help of the average daily energy, produced by the 4 PV that act SP. The average daily pumped flow, for the warm season, is $12.8 \mathrm{~m}^{3} \mathrm{~h}^{-1}$, with values between $11.9 \mathrm{~m}^{3} \mathrm{~h}^{-1}$ in June and 13.3 $\mathrm{m}^{3} \mathrm{~h}^{-1}$ in August, respectively (Figure 6).

The volume of water pumped by SPAPV is directly dependent on the average duration of sunshine, determined as a daily monthly average, therefore the values are daily averages calculated for each month of the warm season. The average daily volume of water, supplied during the vegetation period of the tomatoes, is $110.34 \mathrm{~m}^{3}$ day $^{-1}$, the lowest values being in May, when only 93.47 $\mathrm{m}^{3} \mathrm{day}^{-1}$ is collected, having the maximum accumulated in August (131.27 $\left.\mathrm{m}^{3} \mathrm{day}^{-1}\right)$ For the arrangement of SPVPV with ADP, in the case of the WM variant, 3 watering are required, in May and September, at an interval of approximately 10 days between watering and 9 watering in June, respectively, the interval between watering being smaller, of only 3 days. (Table 9)

Given that in May the flow pumped by SPAPV in one day is $93772 \mathrm{~L}$ and the watering rate for a solarium is $4550 \mathrm{~L}$, it covers the need for 2 solariums. Instead, due to the fact that the distribution at the plant is done with drippers that have to operate at 4 bar for 4 hours, the second solarium cannot be completely watered due to the fact that the operating time of the pump is 7.36 hours. For the same reason, the number of whole solariums, that can be fully irrigated, in the WM variant in September, is also one. In all the other months of the vegetation period, ADP can ensure for the WM variant the watering of two solariums. In the case of the MBF variant, the number of irrigated solariums is limited by the long duration of water distribution at the plant, which is done with the help of microtubes, at which the required operating time is 6 hours. In this case the number of solariums that can be irrigated by this technique is only one for each month of the vegetation period.

For the situation of arrangement with storage tanks (ATS), the water is distributed to the plant by gravity. This system allows the extension of the collection and storage of pumped water, outside the period of water management by direct pumping. For the WM culture variant, the volume of water stored in one day is sufficient for the administration of two watering norms, ie two solariums, regardless of the month from the growing season (Table 10).

Due to the fact that in the case of the MBF variant, the water losses are lower than in the case of WM, the water consumption of the tomatoes is lower and the watering norm is lower, resulting in a larger irrigated surface, but not exceeding two whole solariums. 
Therefore, the use of the arrangement with water storage basin and gravitational distribution, allows to increase the efficiency of the use of water pumped by SPAPV, provided that the water storage tank is installed at a height of at least $2.0 \mathrm{~m}$ and ensures the storage of the appropriate volume for a watering norm. This arrangement has the advantage, that the watering norm can be administered outside the duration of sunlight, including at night in artificial light.

Table 9. Number of solariums, that can be irrigated with ADP

\begin{tabular}{|c|c|c|c|c|c|c|c|c|}
\hline \multirow[t]{2}{*}{ Variant } & \multirow[t]{2}{*}{ Month } & \multicolumn{2}{|c|}{$\begin{array}{l}\text { Pumped } \\
\text { flow }\end{array}$} & \multirow[t]{2}{*}{$\mathbf{n}$} & \multirow{2}{*}{$\begin{array}{c}\mathbf{m} \\
\mathrm{Lm}^{-2}\end{array}$} & \multirow{2}{*}{$\begin{array}{c}\begin{array}{c}\text { Duration of } \\
\text { sunlight }\end{array} \\
\mathrm{h}\end{array}$} & \multirow{2}{*}{$\begin{array}{c}\text { Operating } \\
\text { time of water } \\
\text { dispensers } \\
\mathrm{h}\end{array}$} & \multirow{2}{*}{$\begin{array}{l}\text { Number } \\
\text { of irri- } \\
\text { gated so- } \\
\text { lariums }\end{array}$} \\
\hline & & $\mathrm{m}^{3} \mathrm{~h}^{-1}$ & $\mathrm{Lh}^{-1}$ & & & & & \\
\hline \multirow{6}{*}{ WM } & Apr & 12.7 & 12700 & 3 & 18.2 & 7.36 & 4 & 1.84 \\
\hline & May & 12.5 & 12500 & 6 & 18.2 & 8.54 & 4 & 2.14 \\
\hline & Jun & 11.9 & 11900 & 9 & 18.2 & 8.17 & 4 & 2.04 \\
\hline & $\mathrm{Jul}$ & 12.3 & 12300 & 8 & 18.2 & 9.82 & 4 & 2.46 \\
\hline & Aug & 13.3 & 13300 & 6 & 18.2 & 9.87 & 4 & 2.47 \\
\hline & Sep & 13.2 & 13200 & 3 & 18.2 & 7.70 & 4 & 1.93 \\
\hline \multirow{6}{*}{$\mathrm{MBF}$} & Apr & 12.7 & 12700 & 3 & 16.9 & 7.36 & 6 & 1.23 \\
\hline & May & 12.5 & 12500 & 7 & 16.9 & 8.54 & 6 & 1.42 \\
\hline & Jun & 11.9 & 11900 & 9 & 16.9 & 8.17 & 6 & 1.36 \\
\hline & Jul & 12.3 & 12300 & 10 & 16.9 & 9.82 & 6 & 1.64 \\
\hline & Aug & 13.3 & 13300 & 6 & 16.9 & 9.87 & 6 & 1.65 \\
\hline & Sep & 13.2 & 13200 & 3 & 16.9 & 7.70 & 6 & 1.28 \\
\hline
\end{tabular}

Note: $\mathrm{n}$ - number of watering; $\mathrm{m}$ - watering norm; $\mathrm{h}$ - hours;

Table 10. Number of solariums, that can be irrigated with ATS

\begin{tabular}{|c|c|c|c|c|c|c|c|c|}
\hline \multirow[t]{2}{*}{ Variant } & \multirow[t]{2}{*}{ Month } & \multicolumn{2}{|c|}{$\begin{array}{l}\text { Pumped } \\
\text { flow }\end{array}$} & \multirow[t]{2}{*}{$\mathbf{n}$} & \multirow{2}{*}{$\begin{array}{c}\begin{array}{c}\mathrm{m} \text { for a } \\
\text { solarium }\end{array} \\
\mathrm{m}^{3}\end{array}$} & \multirow{2}{*}{$\begin{array}{c}\begin{array}{c}\text { Duration of } \\
\text { sunlight }\end{array} \\
\mathrm{h}\end{array}$} & \multirow{2}{*}{$\begin{array}{c}\begin{array}{c}\text { Volume of } \\
\text { pumped wa- } \\
\text { ter }\end{array} \\
\mathrm{m}^{3} \text { day }^{-1}\end{array}$} & \multirow{2}{*}{$\begin{array}{l}\text { Number } \\
\text { of irri- } \\
\text { gated so- } \\
\text { lariums }\end{array}$} \\
\hline & & $\mathrm{m}^{3} \mathrm{~h}^{-1}$ & $\mathrm{Lh}^{-1}$ & & & & & \\
\hline \multirow{6}{*}{ WM } & Apr & 12.7 & 12700 & 3 & 45.5 & 7.36 & 93.5 & 2.05 \\
\hline & May & 12.5 & 12500 & 6 & 45.5 & 8.54 & 106.8 & 2.34 \\
\hline & Jun & 11.9 & 11900 & 9 & 45.5 & 8.17 & 97.2 & 2.14 \\
\hline & Jul & 12.3 & 12300 & 8 & 45.5 & 9.82 & 120.8 & 2.65 \\
\hline & Aug & 13.3 & 13300 & 6 & 45.5 & 9.87 & 131.3 & 2.88 \\
\hline & Sep & 13.2 & 13200 & 3 & 45.5 & 7.70 & 101.6 & 2.23 \\
\hline \multirow{6}{*}{$\mathrm{MBF}$} & Apr & 12.7 & 12700 & 3 & 42.25 & 7.36 & 93.5 & 2.21 \\
\hline & May & 12.5 & 12500 & 7 & 42.25 & 8.54 & 106.8 & 2.53 \\
\hline & Jun & 11.9 & 11900 & 9 & 42.25 & 8.17 & 97.2 & 2.30 \\
\hline & Jul & 12.3 & 12300 & 10 & 42.25 & 9.82 & 120.8 & 2.86 \\
\hline & Aug & 13.3 & 13300 & 6 & 42.25 & 9.87 & 131.3 & 3.11 \\
\hline & Sep & 13.2 & 13200 & 3 & 42.25 & 7.70 & 101.6 & 2.40 \\
\hline
\end{tabular}

Note: $\mathrm{n}$ - number of watering; $\mathrm{m}$ - watering norm; $\mathrm{h}$ - hours; 
One way to increase the efficiency of water pumped by SPAPV is possible through the combined use of the two possibilities for localized irrigation, ADP and ATS. On the day scheduled for watering, the water remaining from direct pumping should be stored in tanks for later administration. Considering that the administration of the watering norms can be advanced by one day or can be delayed by one day, in the case of ADP it is possible to reach 2 watered solariums and in the case of ATS to 4 served solariums.

Because the electricity produced by PV, on days when no watering is scheduled is lost, it is recommended to add to the arrangement scheme of accumulator batteries [4948], which lead to an increase in the number of irrigated solariums and increased possibilities for the use of electricity produced for other utilities (lighting, heating, ventilation, etc.)

\subsection{The experimental field from Husasău de Tinca}

Tomato yields, grown organically in drip irrigated solariums from Husasău de Tinca, so as to cover the optimal water consumption (ETRo) had average values (2015-2017) of 86.61 To ha ${ }^{-1}$ for the WM variant and respectively 129.83 To ha $^{-1}$, for the MBF variant. The average yield increase was 29.83 \% for the MBF variant compared to the WM variant. (Table 11.)

Table 11. Organic tomato yields obtained in the solariums from Husasău de Tinca (2015-2017)

\begin{tabular}{|c|c|c|c|c|c|c|c|c|c|c|c|c|c|c|c|c|}
\hline \multirow{3}{*}{ Variants } & \multicolumn{12}{|c|}{ Years } & \multirow{2}{*}{\multicolumn{4}{|c|}{$\begin{array}{c}\text { Average } \\
(2015-2017)\end{array}$}} \\
\hline & \multicolumn{4}{|c|}{2015} & \multicolumn{4}{|c|}{2016} & \multicolumn{4}{|c|}{2017} & & & & \\
\hline & To ha $^{-1}$ & $\%$ & \pm & Sign & To ha-1 & $\%$ & \pm & Sign & To ha-1 & $\%$ & \pm & Sign & To ha-1 & $\%$ & \pm & Sign \\
\hline WM & 84.63 & 100.00 & - & - & 87.97 & 100.00 & - & - & 87.23 & 100.00 & - & - & 86.61 & 100.00 & - & - \\
\hline MBF & 113.60 & 134.24 & 28.97 & $7 * * *$ & 112.03 & 127.35 & 24.06 & $* * *$ & 111.72 & 128.08 & 24.49 & $* * *$ & 112.45 & 129.83 & 25.84 & $* * *$ \\
\hline \multicolumn{17}{|c|}{ Fischer test $(\mathrm{F})$} \\
\hline F $5 \%$ & 5.79 & $\mathrm{FC}^{1}=$ & 2503 & & 5.79 & $\mathrm{FC}^{1}=$ & 1472 & & 5.79 & $\mathrm{FC}^{1}=$ & 713.8 & & 3.55 & $\mathrm{FC}^{1}=$ & 175.9 & \\
\hline F $1 \%$ & 10.92 & & & & 10.92 & & & & 10.92 & & & & 6.01 & & & \\
\hline \multicolumn{17}{|c|}{ Student test $(\mathrm{t})$} \\
\hline $\mathrm{LSD}^{2} 5 \%$ & & & 0.685 & & & & 0.832 & & & & 1.882 & & & & 0.971 & \\
\hline LSD $^{2} 1 \%$ & & & 1.037 & & & & 1.260 & & & & 2.850 & & & & 1.323 & \\
\hline LSD $^{2} 0.1 \%$ & & & 1.667 & & & & 2.024 & & & & 4.579 & & & & 1.813 & \\
\hline
\end{tabular}

${ }^{1}$ The calculated Fischer value; ${ }^{2}$ Limit of the significant difference;

The yields in the years of cultivation varied between 84.63 to $\mathrm{Ha}^{-1}$ (2015) and 87.97 to ha-1 (2016) in the WM variant and between 111.72 to ha-1 (2017) and 113.6 to ha-1 (2015) in the MBF variant. The relative increases in yield were between $27.35 \%$ and $34.24 \%$. The MBF variant brings annual yield increases of 24.06 - 28.97 To ha-1, very significant from a statistical point of view, at the level of accuracy $p>0.01 \%$. Also, the average yield increase of the MBF variant, for the analyzed period, of 25.84 to ha-1 is very statistically significant at the same level of accuracy ( $p>0.01 \%)$.

3.4. Effectiveness of measures to reduce the effects of climate change and energy consumption. The economic efficiency is assessed through, the specific investment required for the arrangement of localized irrigation with direct pumping ADP and with water storage tank (ATS) using tomatoes yields made in 2016 by the two crop systems studied (WM and MBF). Specific Investment (SI), calculated in RON and Euro at the parity of 2020 (1 Euro $=4.84$ Euro) is 1039610 Lei ha-1 $^{-1} 214795$ Euro ha $^{-1}$ ) in case of ADP and respectively 982470 Lei ha-1 (202990 Euro ha-1) in case of ATS (Figure 10).

IPT is longer for WM, of 2.68 years for ADP and 2.53 years for ATS, respectively. IPTs are lower in the MBF variant, 1.54 years at ATS due to higher yields and lower SI than at ADP and 1.63 years for ADP. 


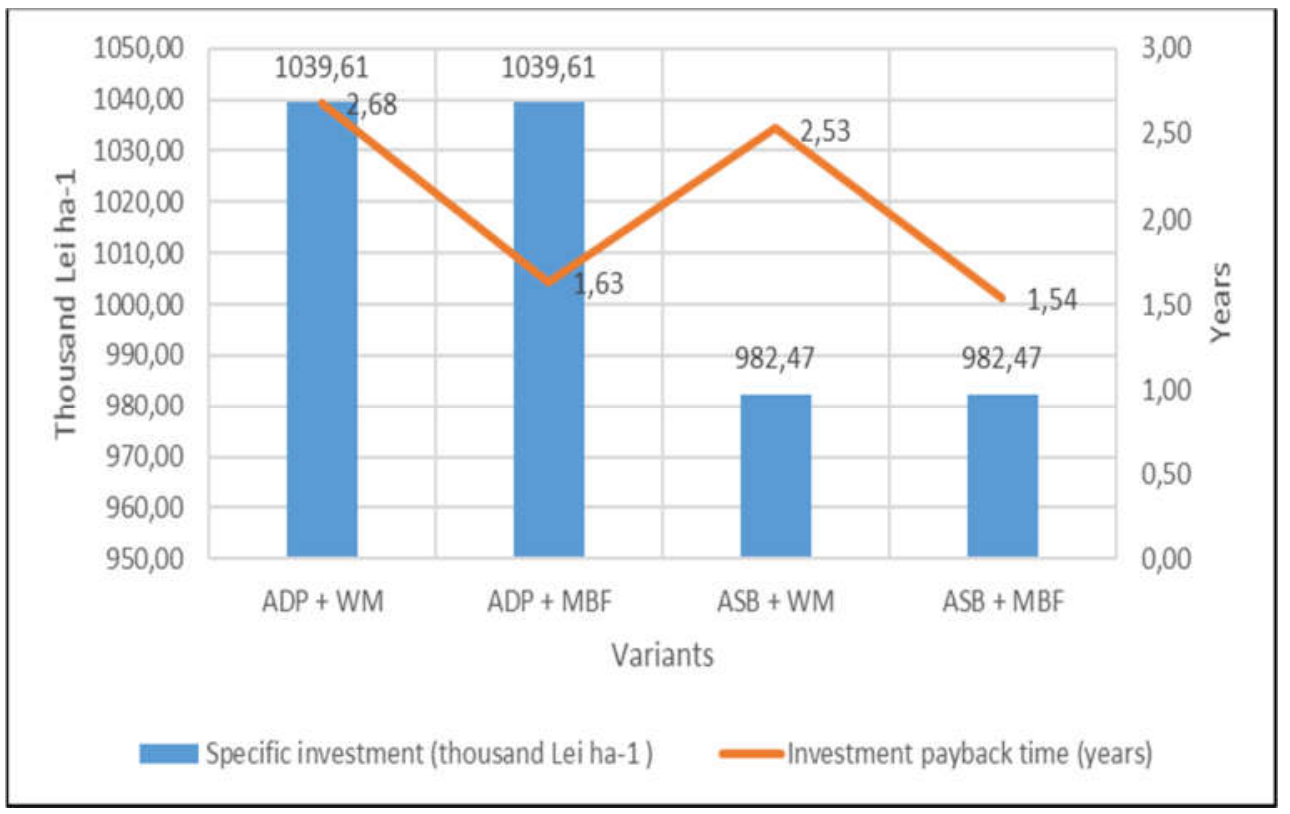

Figure 10. Indicators of economic efficiency

The indices of water use and irrigation water use, in Husasău de Tinca were assessed form 2016 year. WUC values show that the water consumed by irrigated tomatoes is higher in the WM version than in the MBF version, but is used more efficiently in the MBF version, requiring only $0.059 \mathrm{~m}^{3}$ of water to produce $1 \mathrm{~kg}$ of tomatoes, while in the $\mathrm{WM}$ version, 1 $\mathrm{kg}$ of tomatoes requires $0.059 \mathrm{~m}^{3}$ of water consumed. (Table 12.)

Table 12. The indices of water use and irrigation water use in Husasău de Tinca

\begin{tabular}{|c|c|c|c|c|c|c|c|}
\hline \multirow[t]{2}{*}{ Variant } & ETRo & $\Sigma \mathrm{m}$ & $\mathbf{Y}$ & $\begin{array}{c}\text { WUC } \\
(\text { ETRo/Y) }\end{array}$ & $\begin{array}{c}\text { WUE } \\
\text { (Y/ETRo) }\end{array}$ & $\begin{array}{c}\text { IWUC } \\
(\Sigma \mathrm{m} / \mathbf{Y})\end{array}$ & $\begin{array}{c}\text { IWUE } \\
(\mathrm{Y} / \mathbf{\Sigma} \mathrm{m})\end{array}$ \\
\hline & $\mathbf{M}^{3}$ ha $^{-1}$ & $\mathrm{M}^{3} \mathrm{ha}^{-1}$ & $\mathrm{Kg} \mathrm{ha}^{-1}$ & $\mathrm{M}^{3} \mathrm{~kg}^{-1}$ & $\mathrm{Kg} \mathrm{m}^{-3}$ & $\mathrm{M}^{3} \mathrm{~kg}^{-1}$ & $\mathrm{Kg} \mathrm{m}^{-3}$ \\
\hline WM & 6945.7 & 6370 & 87970 & 0.079 & 12.67 & 0.072 & 13.81 \\
\hline $\mathrm{MBF}$ & 6594.0 & 6422 & 112030 & 0.059 & 16.99 & 0.057 & 17.44 \\
\hline Differences & & & & +0.02 & -4.32 & +0.015 & -3.63 \\
\hline
\end{tabular}

The IWUC values are $0.072 \mathrm{~m}^{3} \mathrm{~kg}^{-1}$ in the WM variant, showing that in order to produce 1 $\mathrm{kg}$ of tomatoes, $0.073 \mathrm{~m}^{3}$ of water administered by irrigation are needed, while in the MBF variant, $0.015 \mathrm{~m} 3$ less is needed. IWUC values are lower than WUC values, because, part of the optimal water consumption (ETRo) are done, by the irrigation norm $(\Sigma \mathrm{m})$ which is supplemented by the soil water reserve. In both variants, the values of the coefficients are lower for MBF, showing that the water consumed, regardless of whether it is optimal consumption (ETRo) or irrigation water $(\mathrm{Sm})$, is better preserved, by the soil reserve than in the case of WM.

WUE indicates that in the WM version, $1 \mathrm{~m}^{3}$ of water consumed by irrigation in optimal conditions, corresponds to the tomato yield of $12.67 \mathrm{~kg}$, while in the MBF version, it is $4.32 \mathrm{~kg}$ higher. IWUE, the ratio between yield and water administered by irrigation, shows that for $1 \mathrm{~m}^{3}$ of water $13.81 \mathrm{~kg}$ of tomatoes are obtained, for the WM variant. In the case of the MBF variant, the efficiency of water use is higher, obtaining $17.44 \mathrm{~kg}$ of tomatoes for each $\mathrm{m}^{3}$ of water administered by irrigation. The efficiency of water use is higher for the MBF variant, both for the optimal water consumption $\left(+4.32 \mathrm{~m}^{3} \mathrm{~kg}^{-1}\right)$ and for the irrigation norm $\left(+3.63 \mathrm{~m}^{3} \mathrm{~kg}^{-1}\right)$ administered, indicating the superiority of this measure of water conservation in the soil. 


\section{Discussion}

\subsection{Irrigation regime of tomatoes grown in solariums}

Comparing the ETRo values of tomatoes, obtained starting from the assurance of the air temperature of $80 \%$, with those obtained in the period 1999-2001, using the Piche evaporimeter [63], they are lower than $7153.1 \mathrm{~m}^{3} \mathrm{ha}^{-1}$ for WM and $6958.3 \mathrm{~m}^{3} \mathrm{ha}^{-1}$ respectively, for MBF. If we take into account the ETRo of tomatoes grown in solariums, estimated in 2018, starting from the insurance of not exceeding the precipitation, of $80 \%$ [69], they are higher than those determined from the insurance air temperature, with: $597.5 \mathrm{~m}^{3} \mathrm{ha}^{-1}$ for the WM variant and $668.4 \mathrm{~m}^{3} \mathrm{ha}^{-1}$, respectively, for the MBF variant.

Therefore, estimating the water consumption of tomatoes grown in the solarium, with the help of temperatures, leads to lower values of ETRo and allows the forecast of watering, starting from the measurement of air temperature inside the solarium. We believe that this design method leads to water saving, even in the conditions of the current trend of increasing temperatures during the vegetation period of crops.

\subsection{The main characteristics of SPAPV from tomatoes grown in solariums}

The reduction of the volumes of water for feeding the tomatoes grown in solariums, in the conditions of supplying the pumps of the drip irrigation system, with electricity from the network, leads to energy savings and implicitly to the reduction of production costs.

If we compare the values obtained by estimating global irradiation, using Photovoltaic Geographical Information System [80], with those measured in Timisoara we notice that the values obtained for Oradea are very close, these being in Oradea 342.4 - 438.2 W $\mathrm{m}^{-2}$ and in Timișoara of $351.7-458.2 \mathrm{~W} \mathrm{~m}^{-2}$.

Given the current energy crisis and the photovoltaic potential of the Crișurilor Plain, by using the water pumping of the SPAPVs, the energy independence of the irrigation system is obtained and the energy costs are completely eliminated.

\subsection{The yields in experimental field from Husasău de Tinca}

Average yields achieved in the solariums in the experimental field from Husasău de Tinca, in the period 2015-2017, when the average temperature of the vegetation period was $18.92{ }^{\circ} \mathrm{C}$, are different those from the period 1999-2001, when the temperature was $18.21{ }^{\circ} \mathrm{C}$. Thus, the yield was lower in WM variant (86.61 to ha-1 versus 87.9 to ha- ${ }^{-1}$ ) and higher by 0.85 to ha $^{-1}$ in MBF variant, suggesting the superior efficiency of mulching of tomatoes grown in solariums. Also, the average yields (2000-2002) obtained for tomatoes grown in drip irrigated solariums in Cluj Napoca $(87.7$ to ha-1), where the air temperature is lower than in Crișurilor Plain, were lower than those achieved in Husasău de Tinca.

4.4. Effectiveness of measures to reduce the effects of climate change and energy consumption.

The costs for arranging one hectare of ADP are higher than for ATS by 57140 Lei, due to the fact that, in the second case, it is possible to give up various safety devices (flow meter and manometer) and the tank for fertilizer distribution (the tank for water storage can be used).

The ITPs for the analyzed SPAPV variants exceed 2 years, both for the ADP variant and for the ATS variant, in the case of cultivating tomatoes without mulching (WM) due to the lower ANP value than in the MBF variant. The application of the method of conserving the water reserve from the soil by mulching, determines higher tomato yields, higher ANPs than in the WM variant and implicitly ITPs of SPASPV less than 2 years.

For the cultivation conditions of tomatoes irrigated in solariums, in Cluj Napoca (2000-2002), an average value of IWUC of $0.058 \mathrm{~m}^{3} \mathrm{~kg}^{-1}$ was reported [61], which is very close to the one obtained by us for the MBF variant $\left(0.057 \mathrm{~m}^{3} \mathrm{~kg}^{1}\right)$. This lower value shows a more efficient use of irrigation water. 
The IWUE values obtained with the help of SPAPV in 2016 are higher than those, determined in 2018 of $10.2 \mathrm{~kg} \mathrm{~m}^{-3}$ for $\mathrm{WM}$ and $12.3 \mathrm{~kg} \mathrm{~m}^{-3}$ for MBF, respectively. These show higher tomato yields for the same amount of water administered by irrigation. The large differences between the IWUE values can also be explained by the higher annual precipitations and average temperatures in $2018\left(702.2 \mathrm{~mm}, 12.45{ }^{\circ} \mathrm{C}\right)$ than in $2016,(693.2$ $\mathrm{mm}, 10.93{ }^{\circ} \mathrm{C}$ ) which determined the coverage in a higher percentage of water consumption of tomatoes from the soil water reserve.

\section{Conclusions}

The average annual temperature with the insurance of exceeding $20 \%$ at the Oradea Meteorological Station, of 12.2 'C, was registered in the agricultural year 2015-2016. For the vegetation period of tomatoes grown in solariums, the average air temperature was $18.8^{\circ} \mathrm{C}$, while inside solariums it was $22.8^{\circ} \mathrm{C}$. PET has monthly values between $75.31 \mathrm{~mm}$ in April and $171.46 \mathrm{~mm}$ in July.

The amount of water needed to cover the water consumption of tomatoes, is in the case of the WM variant of $6370 \mathrm{~m}^{3} \mathrm{ha}^{-1}$, requiring 35 waterings, and for MBF $6422 \mathrm{~m}^{3} \mathrm{ha}^{-1}$, administered in 38 waterings.

Horizontal global solar irradiation, accumulated during the vegetation period of tomatoes, grown in solariums (Apr-Sep) is $1005.3 \mathrm{kWh} \mathrm{m}^{-2}$, while in the case of PVs, inclined at $45^{\circ}$, it is estimated at $1038.9 \mathrm{kWh} \mathrm{m}^{-2}$. The average hourly value is $391.8 \mathrm{~W} \mathrm{~m}^{-2}$, with monthly values between $342.4 \mathrm{~W} \mathrm{~m}^{-2}$, in June and $438.2 \mathrm{~W} \mathrm{~m}^{-2}$ in August.

The used SPAPV is composed of the SP produced by Lorentz, PS600 BADU Top12, which is delivered together with the PS 600 controller and 4 PVs AE320M6-60, produced in Germany, with supplied power of $320 \mathrm{~W}$ at a yield of $19.3 \%$.

The average daily flow pumped by SPAPV, for the vegetation season is $12.8 \mathrm{~m}^{3} \mathrm{~h}^{-1}$, with values between $11.9 \mathrm{~m}^{3} \mathrm{~h}^{-1}$ in June and $13.3 \mathrm{~m}^{3} \mathrm{~h}^{-1}$ in August, respectively. The average daily water volume is $110.34 \mathrm{~m}^{3} \mathrm{day}^{-1}$, with the lowest values in May when only 93.5 $\mathrm{m}^{3}$ day $^{-1}$ are collected, with the maximum accumulated in August $\left(131.3 \mathrm{~m}^{3}\right.$ day $\left.^{-1}\right)$.

In the case of ADP, the WM variant can be watered entirely 2 solariums, except in September when only one is watered. ADP ensures for the MBF variant the watering of 2 whole solariums for the entire vegetation period. ATS increases the efficiency of irrigation water use and it is possible to water 2 whole solariums for both variants analyzed. By combining the two possibilities of localized irrigation, ADP and ATS, by storing the pumped water in tanks and by administering the watering norm in advance or late by one day, it is possible to reach 4 solariums served.

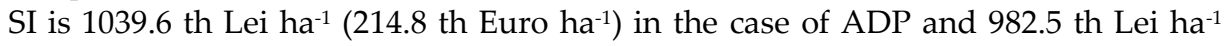
(203.0 th Euro ha-1) in the case of ATS. The IPT for the WM variant is between 2.53 years for ATS and 2.68 years for ADP, respectively. The IPT.s are, in the case of the MBF variant, 1.54 years for ATS and 1.63 years for MBF and ADP, respectively.

IWUC values show that irrigation water is used more efficiently in the case of the MBF variant, the volume of irrigation water required to produce a ton of tomatoes is 57.3 $\mathrm{m}^{3}$ and $72.4 \mathrm{~m}^{3} \mathrm{to}^{-1}$, in the WM variant. The IWUE values show that for $1 \mathrm{~m}^{3}$ of water administered by irrigation, $13.8 \mathrm{~kg}$ of tomatoes are obtained, for the WM variant and respectively $17.4 \mathrm{~kg}$ of tomatoes for each $\mathrm{m}^{3}$ of water administered, for the MBF variant.

For the pedoclimatic conditions in Crișurilor Plain, the measures taken to reduce the effects of global climate change and to save electricity are economically efficient and in terms of the efficiency of irrigation water use.

In order to save water and electricity, in the case of tomatoes grown in solariums, the arrangement, for localized irrigation with water storage tank (ATS) and the culture variant with mulching using black foil (MBF) it is recommended.

\section{Patents}


Author Contributions: Conceptualization, M.C. and N.C.S.; methodology, O.M.; software, M.C.; validation, I.B., A.S. and T.V.; formal analysis, A.V.; investigation, A.P. and M.L.C.; data curation, C.O.; writing-original draft preparation, N.C.S. and M.C.; writing-review and editing, M.L.C.; supervision, N.C.S.; All authors have read and agreed to the published version of the manuscript."

Funding: This research received no external funding.

Acknowledgments: The authors thank Prof. Dr. Eng. Sorin Curilă (University of Oradea, Faculty of Electrical Engineering and Information Technology) for technical support in the design of the solar pump and solar panels.

Conflicts of Interest: The authors declare no conflict of interest.

\section{References}

1. Xu, J.; Zhu, X.; Li, M.; Qiu, X.; Wang, D.; Xu, Z. Shifts in Dry-Wet Climate Regions over China and Its Related Climate Factors between 1960-1989 and 1990-2019. Sustainability 2022, 14, 719. https://doi.org/10.3390/su14020719

2. Mizik, T. Climate-Smart Agriculture on Small-Scale Farms: A Systematic Literature Review. Agronomy 2021, 11, 1096. https://doi.org/10.3390/agronomy11061096

3. Șmuleac, L.; Rujescu, S.; Șmuleac, A.; Imbrea, F.; Radulov, I.; Manea, D.; Ienciu, A.; Adamov, T.; Pașcalau, R. Impact of Climate Change in the Banat Plain, Western Romania, on the Accessibility of Water for Crop Production in Agriculture. Agriculture 2020, 10, 437; https://doi.org/10.3390/agriculture10100437

4. Dawley, S.; Zhang, Y.; Liu, X.; Jiang, P.; Tick, G.R.; Sun, H.; Zheng, C.; Chen, L. Statistical Analysis of Extreme Events in Precipitation, Stream Discharge, and Groundwater Head Fluctuation: Distribution, Memory, and Correlation. Water 2019, 11, 707. https://doi.org/10.3390/w11040707

5. Ziernicka-Wojtaszek, A.; Kopcińska, J. Variation in Atmospheric Precipitation in Poland in the Years 20012018. Atmosphere 2020, 11, 794. https://doi.org/10.3390/atmos11080794

6. Liao, Y.; Chen, D.; Han, Z.; Huang, D. Downscaling of Future Precipitation in China's Beijing-Tianjin-Hebei Region Using a Weather Generator. Atmosphere 2022, 13, 22. https://doi.org/10.3390/atmos13010022

7. Fadl, M.E.; Abuzaid, A.S.; AbdelRahman, M.A.E.; Biswas, A. Evaluation of Desertification Severity in El-Farafra Oasis, Western Desert of Egypt: Application of Modified MEDALUS Approach Using Wind Erosion Index and Factor Analysis. Land 2022, 11, 54. https://doi.org/10.3390/land11010054

8. Kaenzig, R.; Piguet, E. Toward a Typology of Displacements in the Context of Slow-Onset Environmental Degradation. An Analysis of Hazards, Policies, and Mobility Patterns. Sustainability 2021, 13, 10235. https://doi.org/10.3390/su131810235

9. Liu, M.; Guo, Y.; Wang, Y.; Hao, J. Changes of Extreme Agro-Climatic Droughts and Their Impacts on Grain Yields in Rain-Fed Agricultural Regions in China over the Past 50 Years. Atmosphere 2022, 13, 4. https://doi.org/10.3390/atmos13010004

10. Koch, M.T.; Pawelzik, E.; Kautz, T. Chloride Changes Soil-Plant Water Relations in Potato (Solanum tuberosum L.). Agronomy 2021, 11, 736. https://doi.org/10.3390/agronomy11040736

11. Heil, K.; Lehner, A.; Schmidhalter, U. Influence of Climate Conditions on the Temporal Development of Wheat Yields in a LongTerm Experiment in an Area with Pleistocene Loess. Climate 2020, 8, 100. https://doi.org/10.3390/cli8090100

12. Ogunkanmi, L.; MacCarthy, D.S.; Adiku, S.G.K. Impact of Extreme Temperature and Soil Water Stress on the Growth and Yield of Soybean (Glycine max (L.) Merrill). Agriculture 2022, 12, 43. https://doi.org/10.3390/agriculture12010043

13. Dimitriadou, S.; Nikolakopoulos, K.G. Evapotranspiration Trends and Interactions in Light of the Anthropogenic Footprint and the Climate Crisis: A Review. Hydrology 2021, 8, 163. https://doi.org/10.3390/hydrology8040163

14. Qaseem, M.F., Qureshi, R. \& Shaheen, H. Effects of Pre-Anthesis Drought, Heat and Their Combination on the Growth, Yield and Physiology of diverse Wheat (Triticum aestivum L.) Genotypes Varying in Sensitivity to Heat and drought stress. Sci Rep 2019, 9, 6955. https://doi.org/10.1038/s41598-019-43477-z

15. Mazhayski, Y.;Pavlov, A.; Miseckaite, O. Crops Water Consumption and Vertical Soil Moisture Exchange. AGROFOR International Journal 2021, 6(1), 57-64. https://doi.org/10.7251/AGRENG2101057M

16. Long, A.; Zhang, P.; Hai, Y.; Deng, X.; Li, J.; Wang, J. Spatio-Temporal Variations of Crop Water Footprint and Its Influencing Factors in Xinjiang, China during 1988-2017. Sustainability 2020, 12, 9678. https://doi.org/10.3390/su12229678

17. Chaleeraktrakoon, C.; Punyawansiri, S. Impact of Climate Variability and Change on Crop Water Consumption. Advances in Geosciences, 2012, 21-29. https://doi.org/10.1142/9789814405713 0003

18. Cho, G.-H.; Ahmad, M.J.; Choi, K.-S. Water Supply Reliability of Agricultural Reservoirs under Varying Climate and Rice Farming Practices. Water 2021, 13, 2988. https://doi.org/10.3390/w13212988

19. Arshad, A.; Zhang, Z.; Zhang, W.; Gujree, I. Long-Term Perspective Changes in Crop Irrigation Requirement Caused by Climate and Agriculture Land Use Changes in Rechna Doab, Pakistan. Water 2019, 11, 1567. https://doi.org/10.3390/w11081567

20. Saeed, F.H.; Al-Khafaji, M.S.; Al-Faraj, F.A.M. Sensitivity of Irrigation Water Requirement to Climate Change in Arid and SemiArid Regions towards Sustainable Management of Water Resources. Sustainability 2021, 13, 13608. https://doi.org/10.3390/su132413608 
21. Cáceres, G.; Millán, P.; Pereira, M.; Lozano, D. Smart Farm Irrigation: Model Predictive Control for Economic Optimal Irrigation in Agriculture. Agronomy 2021, 11, 1810. https://doi.org/10.3390/agronomy11091810

22. Burlacu, S.; Vasilache, P.C.; Velicu, E.R.; Curea, Ș-C.; Margina, O. Management of Water Resources at Global Level. In Proceedings of the 3rd International Conference on Economics and Social Sciences, Romania, 15-16, October 2020, $998-1009$. DOI: $10.2478 / 9788395815072-100$

23. Rakhecha PR. Management of water resources in India. Int J Hydro. 2019, 3(5):354-360. DOI: 10.15406/ijh.2019.03.00200

24. Campi, P.; Navarro, A.; Giglio, L.; Palumbo, A.D.; Mastrorilli, Marcello. Modelling for water supply of irrigated cropping systems on climate change. Italian Journal of Agronomy 2012, 7:e14, 93-99. https://doi.org/10.4081/ija.2012.e14

25. Al-Omran, A.; Louki, I.; Alkhasha, A.; Abd El-Wahed, M.H.; Obadi, A. Water Saving and Yield of Potatoes under Partial RootZone Drying Drip Irrigation Technique: Field and Modelling Study Using SALTMED Model in Saudi Arabia. Agronomy 2020, 10, 1997. https://doi.org/10.3390/agronomy10121997

26. Kurbanbaev, S.; Karimova, O.; Turlibaev, Z.; Baymuratov, R. Effective and rational use of irrigation water in the conditions of the republic of Karakalpakstan. In Proceedings of E3S Web of Conferences, 264, 04023, Conmenchydro, 02, June, 2021. https://doi.org/10.1051/e3sconf/202126404023

27. Śpitalniak, M.; Bogacz, A.; Zięba, Z. The Assessment of Water Retention Efficiency of Different Soil Amendments in Comparison to Water Absorbing Geocomposite. Materials 2021, 14, 6658. https://doi.org/10.3390/ma14216658

28. Mugandani, R.; Mwadzingeni, L.; Mafongoya, P. Contribution of Conservation Agriculture to Soil Security. Sustainability 2021, 13, 9857. https://doi.org/10.3390/su13179857

29. Chowdhury, T.; Chowdhury, H.; Ahmed, A.; Park, Y.-K.; Chowdhury, P.; Hossain, N.; Sait, S.M. Energy, Exergy, and Sustainability Analyses of the Agricultural Sector in Bangladesh. Sustainability 2020, 12 , 4447. https://doi.org/10.3390/su12114447

30. Rokicki, T.; Perkowska, A.; Klepacki, B.; Bórawski, P.; Bełdycka-Bórawska, A.; Michalski, K. Changes in Energy Consumption in Agriculture in the EU Countries. Energies 2021, 14, 1570. https://doi.org/10.3390/en14061570

31. Nabavi-Pelesaraei, A.; Azadi, H.; Van Passel, A.; Saber, Z.; Hosseini-Fashami, F.; Mostashari-Rad, F.; Ghasemi-Mobtaker, H. Prospects of solar systems in production chain of sunflower oil using cold press method with concentrating energy and life cycle assessment. Energy 2021, 223, 120117. https://doi.org/10.1016/j.energy.2021.120117

32. Galforda, G.L.; Peñaa, O.; Sullivan, A.K.; Nashab, J.; Gurwick, Noel,; Pirolli, G.; Richards, M.; White, J.; Wollenberg, E. Agricultural development addresses food loss and waste while reducing greenhouse gas emissions. Science of Total Environment 2020, 699, 134318. https://doi.org/10.1016/j.scitotenv.2019.134318

33. Arodudu, O.; Helming, K.; Wiggering, H.; Voinov, A. Bioenergy from Low-Intensity Agricultural Systems: An Energy Efficiency Analysis. Energies 2017, 10, 29. https://doi.org/10.3390/en10010029

34. Hossain, J. Wind Energy Resource. In book: Renewable energy engineering and technology. Publisher: TERI Press, India, 2021, $445-471$.

35. Ravi, S.; Macknick, J.; Lobell, D.; Fieldd, C.; Ganesan, K.; Jain, R.; Elchinger, M.; Stoltenberg, B. Colocation opportunities for large solar infrastructures and agriculture in drylands. Applied Energy 2016, 165(1), 383-392. https://doi.org/10.1016/j.apenergy.2015.12.078

36. Chazarra-Zapata, J.; Molina-Martínez, J.M.; Cruz, F.-J.P.d.l.; Parras-Burgos, D.; Ruíz Canales, A. How to Reduce the Carbon Footprint of an Irrigation Community in the South-East of Spain by Use of Solar Energy. Energies 2020, $13,2848$. https://doi.org/10.3390/en13112848

37. Bahadori, M.N. Solar water Pumbping, Solar Energgy, 1978, 21(4), 307-316. https://doi.org/10.1016/0038-092X(78)90007-5

38. Gopal, C.; Mohanraj, M.; Chandramohan, P.; Chandrasekar, P. Renewablw energy source water pumping systems, A literature review, Renewable and Sustainable Energy Reviews, 2013, 25, 351-370. https://doi.org/10.1016/j.rser.2013.04.012

39. Bloomberg New Energy Finance (BNEF), Costurile de producție in scădere ale panourilor solare, trezesc apetitul pentru energia solară, [Decreasing production costs of solar panels arouse the appetite for solar energy], 2016, Available online: https://solarcenter.ro/grafice-care-releva-cresterea-productiei-de-energie-regenerabila/ (accessed on 14.09.2020)

40. Closas, A.; Rap, E. Solar-based groundwater pumping for irrigation: Sustainability, policies, and limitations, Elsevier - Energy Policy, 2017, 104, 33-37. https://doi.org/10.1016/j.enpol.2017.01.035

41. Mahdi M.M., Gaddoa A. An Experimental Study on Optimization of a Photovoltaic Solar Pumping System Used for Solar Domestic Hot Water System under Iraqi Climate. In: Solanki V., Hoang M., Lu Z., Pattnaik P. (eds) Intelligent Computing in Engineering. Advances in Intelligent Systems and Computing 2020, 1125. Springer, Singapore. https://doi.org/10.1007/978-98115-2780-7 78

42. Wazed, S.M.; Hughes, B.R.; O'Connor, D.; Calautit, J.K. Solar Driven Irrigation Systems for Remote Rural Farms. Energy Procedia 2017, 142, 184-191. https://doi.org/10.1016/j.egypro.2017.12.030

43. Burneya, J.; Wolteringb, L.; Burkec, M.; Naylora, R.; Pasternak, D. Solar-powered drip irrigation enhances food security in the Sudano-Sahel. In PNAS 2010, 107 (5), 1848-1853. https://doi.org/10.1073/pnas.0909678107

44. Renu, B.B.; Prasad, B.; Sastry, O.S.; Kumar, A.; Bangar, M. Optimum sizing and performance modeling of Solar Photovoltaic (SPV) water pumps for different climatic conditions, Solar Energy, 2017, 155, 1326-1338. https://doi.org/10.1016/j.solener.2017.07.058

45. Arthishri, K.; Ramalingam, B.; Parkavi, K.; Sishaj, P.S.; Amirtharajan, R. Maximum Power Point Tracking of Photovoltaic Generation System using Artificial Neural Network with Improved Tracking Factor, Journal of Applied Sciences, 2014, 14(16), 1858-1864. Doi: $10.3923 / j a s .2014 .1858 .1864$ 
46. Mokeddema, A.; Midounb, A.; Kadric, D.; Said, H.; Iftikhar, A.R. Performance of a directly-coupled PV water pumping system, Elsevier, Energy Conversion and Management, 2011, 52(10), 3089-3095. http://dx.doi.org/10.1016/j.enconman.2011.04.024

47. Isikwue, M.O.; Ochedikwu Anthea, E.F.; Onoja, S.B. Small Farm Gravity Drip Irrigation System for Crop Production, Greener Journal of Science, Engineering and Technological Research, 2016, 6(2), 48-54. http://doi.org/10.15580/GJSETR.2016.2.061416105

48. Naval, N.; Yusta, J.M. Water-Energy Management for Demand Charges and Energy Cost Optimization of a Pumping Stations System under a Renewable Virtual Power Plant Model. Energies 2020, 13, 2900. https://doi.org/10.3390/en13112900

49. Yahyaoui, I.; Tadeo, F.; Vieira Segattoa, M. Energy and water management for drip-irrigation of tomatoes in a semi-arid district, Agricultural Water Management, Elsevier 2017, 183C, 4 - 15. https://ideas.repec.org/a/eee/agiwat/v183y2017icp4-15.html

50. Dursun, M.; Ozden, S. Control of soil moisture with radio frequency in a photovoltaic-powered drip irrigation system, Turkish Journal of Electrical Engineering \& Computer Sciences, 2015, 23, 447 - 458. https://journals.tubitak.gov.tr/elektrik/issues/elk-15-232/elk-23-2-9-1302-22.pdf.

51. Grumeza, N.; Merculiev, O.; Klepș, Cr. Prognoza și programarea aplicării udărilor în sistemele de irigații. [Forecasting and scheduling the application of the watering in irrigation systems] Editura CERES București, 1989 [CERES Publishing House, Bucharest, 1989].

52. El Hafyani, M.; Essahlaoui, A.; Fung-Loy, K.; Hubbart, J.A.; Van Rompaey, A. Assessment of Agricultural Water Requirements for Semi-Arid Areas: A Case Study of the Boufakrane River Watershed (Morocco). Appl. Sci. 2021, 11, 10379. https://doi.org/10.3390/app112110379.

53. Jamshidi, S.; Zand-Parsa, S.; Naghdyzadegan Jahromi, M.; Niyogi, D. Application of A Simple Landsat-MODIS Fusion Model to Estimate Evapotranspiration over A Heterogeneous Sparse Vegetation Region. Remote Sens. 2019, 11, 741. https://doi.org/10.3390/rs11070741

54. Aguilar, A.L.; Flores, H.; Crespo, G.; Marín, M.I.; Campos, I.; Calera, A. Performance Assessment of MOD16 in Evapotranspiration Evaluation in Northwestern Mexico. Water 2018, 10, 901. https://doi.org/10.3390/w10070901

55. Montazar, A.; Krueger, R.; Corwin, D.; Pourreza, A.; Little, C.; Rios, S.; Snyder, R.L. Determination of Actual Evapotranspiration and Crop Coefficients of California Date Palms Using the Residual of Energy Balance Approach. Water 2020, $12,2253$. https://doi.org/10.3390/w12082253

56. Xu, C.Y.; Singh, V.P., Evaluation and generalization of temperature-based methods for calculating evaporation. Hydrol. Process, 2001, 15, pp: 305-319. https://doi.org/10.1002/hyp.119

57. Singh, Y.P.; Paradkar, V.D.; Sharma, V.; Kour, M. Calculation of Reference Evapotranspiration (ETo) for Chhattisgarh Plains, Ind. J. Pure App. Biosci. 2019, 7(4), 401-405. http://dx.doi.org/10.18782/2320-7051.7633

58. Tigkas, D., Vangelis, H. \& Tsakiris, G. Implementing Crop Evapotranspiration in RDI for Farm-Level Drought Evaluation and Adaptation under Climate Change Conditions. Water Resour Manage 2020, 34, 4329-4343. https://doi.org/10.1007/s11269-020$\underline{02593-6}$

59. Buttaro, D.; Santamaria, P.; Signore, A.; Cantore, V.; Boari, F.; Montesano, F.F.; Parente, A. Irrigation Management of Greenhouse Tomato and Cucumber Using Tensiometer: Effects on Yield, Quality and Water Use, The Effects of Irrigation and Drainage on Rural and Urban Landscapes, Patras, Greece, ELSEVIER, Agriculture and Agricultural Science Procedia 2015, 4: 440444. https://doi.org/10.1016/j.aaspro.2015.03.050

60. Màtè, M.D.; Szalòkinè Zima, Il. Development and yield of field tomato under different water supply, Research Journal of Agricultural Science, 2020, 52(1): 167-177.

61. Dîrja, M.; Budiu, V.; Păcurar, I.; Jurian, M. Research regarding the water consumption of tomatoes, green pepper and cucumbers cultivated in solariums, Journal of Central European Agriculture (online), 2003, 4(3):265-272. file://D:/Downloads/jcea43_10\%20(2).pdf.

62. Hanping, M.; Ullah, I.; Jiheng, N.; Javed, Q.; Azeem, A. Estimating tomato water consumption by sap flow measurement in response to water stress under greenhouse conditions, Journal of Plant Interactions, 2017, 12(1), 402-413. DOI: $10.1080 / 17429145.2017 .1373869$

63. Domuța, C.; Cărbunaru, M.; Şandor, M.; Bandici, Gh.; Samuel, A.; Stanciu, A.; Domuța, Cr. Use of the Piche evaporimeter in the irrigation sheduling of the tomatoes in the conditions from the solarium, Annals of University of Oradea, Fascicle: Environmental Protection, 2007, XII, 40-45.

64. Cărbunar, Mh. Contribuții la studiul mulcirii solului și irigării prin picurare la cultura tomatelor în solarii acoperite cu folii de lungă durată [Contributions to the study of soil mulching and drip irrigation to the cultivation of tomatoes in solariums covered with long-lasting foils] PhD Thesis, USAMV Cluj Napoca, 2005.

65. Distretto di Bihor - $\quad$ Wikipedia. Available online: https://it.wikipedia.org/wiki/Distretto_di_Bihor\#/media/File:Bihor_in_Romania.svg (accesed on 14 January 2022).

66. Bihor County Map of Romania. Available online: https://pe-harta.ro/bihor/ (accesed on 14 January 2022)

67. National Meteorological Agency. Available online: http://www.meteoromania.ro/ (accessed on 20 February 2020)

68. Ardelean, M.; Sestraș, T.; Cordea, M. Tehnică Experimentală Horticolă [Experimental horticultural technique], Editura Academicpres [Academicpres Publishing House] Cluj-Napoca, Romania, 2005, 110

69. Ciupak, M.; Ozga-Zieliński, B.; Tokarczyk, T.; Adamowski, J. A Probabilistic Model for Maximum Rainfall Frequency Analysis. Water 2021, 13, 2688. https://doi.org/10.3390/w13192688

70. Thornthwaite, C.W. An approach toward a rational classification of climate. Geographical Review, 1948, 38(1) pp: 55-94. https://doi.org/10.2307/210739 
71. Tigkas, D.; Vangelis, H.; Tsakiris, G. Drought characterisation based on an agriculture-oriented standardised precipitation index. Theoretical and Applied Climatology, 2019, 135(3-4), pp: 1435-1447. https://doi.org/10.1007/s00704-018-2451-3

72. Zheng, S.; Ni, K.; Ji, L.; Zhao, C.; Chai, H.; Yi, X.; He, W.; Ruan, J. Estimation of Evapotranspiration and Crop Coefficient of Rain-Fed Tea Plants under a Subtropical Climate. Agronomy 2021, 11, 2332https://doi.org/10.3390/agronomy11112332

73. Chand, J.; Hewa, G.; Hassanli, A.; Myers, B. Evaluation of Deficit Irrigation and Water Quality on Production and Water Productivity of Tomato in Greenhouse. Agriculture 2020, 10, 297. https://doi.org/10.3390/agriculture10070297

74. Tanaskovik, V.; Cukaliev, O.; Markoski, M.; Mitkova, T.; Vukelic Shutoska, M. Soil Moisture Dynamics in Different Irrigation Regimes of Tomato Crop. Agriculture and Forestry, 62(1), 415-429. http://www.agricultforest.ac.me/paper.php?id=2553

75. Calero-Lara, M.; López-Luque, R.; Casares, F.J. Methodological Advances in the Design of Photovoltaic Irrigation. Agronomy 2021, 11, 2313. https://doi.org/10.3390/agronomy11112313

76. Sharu, E.H.; Ab Razak, M.S. Hydraulic Performance and Modelling of Pressurized Drip Irrigation System. Water 2020, $12,2295$. https://doi.org/10.3390/w12082295

77. Lorentz. Solar-powered Water Pumpingfor Vineyard Irrigation, Case Study, 2011, https://lorentz.ro/wpcontent/uploads/2019/12/lorentz_casestudy vineyardoregon_usa_en.pdf. [Accesed in March, 2021]

78. Lorentz. PS 600 BADU Top 12, Solar Operated Centrifugal Surface Pump, 2019, http://client.lpelectric.ro/doc/lorentz ps600 badutop.pdf. [Accesed in 21 May, 2021]

79. Paulescu, M.; Schlett, Z. A simplified but accurate spectral solar irradiance model. Theoretical and Applied Climatology, 2003, 75, 203-212., https://link.springer.com/content/pdf/10.1007/s00704-003-0731-y.pdf

80. European Comision. Phoytovoltaic Geographical Information System (PVGIS), 2021, https://re.jrc.ec.europa.eu/pvg_tools/en/\#TMY. [Accesed in 14 May 2021]

81. Paulescu. M.; Paulescu, E.; Gavrilă, P.; Bădescu, V. Weather modeling and forecasting of PV systems operation, Springer, London. 2013, https://www.springer.com/gp/book/9781447146483.

82. Victron Energy. BlueSolar Monocrystalline Panels. 2020, https://www.victronenergy.com/upload/documents/DatasheetBlueSolar-Monocrystalline-Panels-EN.pdf. [Accesed March 27, 2021]

83. Tamesol. Energia para vivir, 2020, https://www.victronenergy.com/upload/documents/Datasheet-BlueSolar-MonocrystallinePanels-EN.pdf. [Acccesed March, 23, 2021]

84. SunPower. Solar Panel, SGSP Series, 2016, https://www.sungoldsolar.com/Rigid-Solar-Panel-SGSP-series.html. [Accesed in March 24, 2021]

85. ENF. Solar Trade Platform and Directory of Solar Companies, 2019, https://www.enfsolar.com/pv/paneldatasheet/crystalline/1574. [Accesed in sept. 2019]

86. AE Solar. Product List, 2020, https://catalog.climatherm.ro/energii-regenerabile/sisteme-fotovoltaice/panou-fotovoltaic/panou320w. [Accesed March 30, 2020]

87. Crespo Chacón, M.; Rodríguez Díaz, J.A.; García Morillo, J.; McNabola, A. Pump-as-Turbine Selection Methodology for Energy Recovery in Irrigation Networks: Minimising the Payback Period. Water 2019, 11, 149. https://doi.org/10.3390/w11010149

88. Jayathilaka, A.K.K.R. Operating Profit and Net Profit: Measurements of Profitability. Open Access Library Journal, 2020, 7: e7011. https://doi.org/10.4236/oalib.1107011

89. Li, X.; Jiang, W.; Duan, D. Spatio-temporal analysis of irrigation water use coefficients in China. Journal of Environmental Management 2020, 262, 110242 https://doi.org/10.1016/j.jenvman.2020.110242

90. Pinnamaneni, S.R.; Anapalli, S.S.; Fisher, D.K.; Reddy, K.N. Water Use Efficiencies of Different Maturity Group Soybean Cultivars in the Humid Mississippi Delta. Water 2021, 13, 1496. https://doi.org/10.3390/w13111496 